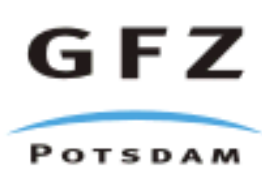

Originally published as:

Trumbull, R. B., Krienitz, M.-S., Gottesmann, B., Wiedenbeck, M. (2008): Chemical and boron-isotope variations in tourmalines from an S-type granite and its source rocks: the Erongo granite and tourmalinites in the Damara Belt, Namibia. - Mineralogy and Petrology, 155, 1, 1-18,

DOI: $10.1007 / \mathrm{s} 00410-007-0227-3$. 


\title{
Chemical and boron-isotope variations in tourmalines from an S-type granite and its source rocks: the Erongo granite and tourmalinites in the Damara Belt, Namibia
}

\author{
R.B. Trumbull, M.-S. Krienitz, B. Gottesmann, M. Wiedenbeck \\ GeoForschungsZentrum Potsdam, Telegrafenberg, 14473 Potsdam, Germany
}

Key words: SIMS, tourmaline orbicules, tourmalinite, boron isotope fractionation, liquid immiscibility, granite

\begin{abstract}
Tourmaline is widespread in metapelites and pegmatites from the Neoproterozoic Damara Belt, which form the basement and potential source rocks of the Cretaceous Erongo granite. This study traces the B-isotope variations in tourmalines from the basement, from the Erongo granite and from its hydrothermal stage. Tourmalines from the basement are alkali-deficient schorl-dravites, with Bisotope ratios typical for continental crust $\left(\delta^{11} B\right.$ average $-8.4 \% \pm 1.4, n=11$; one sample at $\left.-13 \%, n=2\right)$. Virtually all tourmaline in the Erongo granite occurs in distinctive tourmaline-quartz orbicules. This "main-stage" tourmaline is alkali-deficient schorl (20-30\% X-site vacancy, $\mathrm{Fe} /(\mathrm{Fe}+\mathrm{Mg}) 0.8$ to 1$)$, with uniform B-isotope compositions $\left(\delta^{11} \mathrm{~B}-8.7 \%_{0} \pm 1.5, \mathrm{n}=49\right)$ that are indistinguishable from the basement average, suggesting that boron was derived from anatexis of the local basement rocks with no significant shift in isotopic composition. Secondary, hydrothermal tourmaline in the granite has a bimodal B-isotope distribution with one peak at about $-9 \%$, like the main-stage tourmaline and a second at $-2 \%$. We propose that the tourmaline-rich orbicules formed late in the crystallization history from an immiscible Na-B- Fe-rich hydrous melt. The massive precipitation of orbicular tourmaline nearly exhausted the melt in boron and the shift of $\delta^{11} \mathrm{~B}$ to $-2 \%$ in secondary tourmaline can be explained by Rayleigh fractionation after about $90 \%$ B-depletion in the residual fluid.
\end{abstract}




\section{Introduction}

Tourmaline is the dominant mineral host for boron in most crustal rocks, it is a chemically resistant detrital phase in sediments and a common gangue mineral in a wide range of hydrothermal ore deposits. Tourmaline is therefore at the center of interest in boron isotope geochemistry and its applications to fluid-related processes including hydrothermal ore formation, subduction zone dehydration and arc magma-genesis, crustal metamorphism and anatexis (e.g., Smith and Yardley, 1996; Chaussidon and Appel, 1997; Tonarini et al., 1998; Dyar et al., 1999; Jiang et al., 1999; Taylor et al., 1999; Trumbull and Chaussidon, 1999; Kasemann et al., 2000; Altherr et al., 2004; Pesquera et al., 2005). In-situ microanalysis of B-isotope composition in tourmaline by SIMS has the great advantage over bulk techniques that contamination with mineral inclusions can be largely avoided and variations in isotope ratios at the sub-grain scale can be resolved, which allows direct coupling of isotopic and chemical composition with important petrographic features such as mineral zoning, replacement or overgrowth textures (Nakano and Nakamura, 2001; Chaussidon and Appel, 1997; Matthews et al., 2003; Altherr et al., 2004; Marschall et al., 2006).

This paper reports in-situ B-isotope and chemical compositions in tourmaline from samples that represent different stages in a sequence of crustal anatexis, granitic differentiation and post-magmatic metasomatism in the Neoproterozoic Damara Belt of Namibia. Our study is based on two sets of samples. The first and more extensive sample suite is from the Early Cretaceous Erongo granite, which formed in the Central Zone of the Damara Belt during the intense magmatism that preceded the opening of the Atlantic Ocean. The peraluminous bulk composition of the Erongo granite, its trace element characteristics and, in particular its Sr-, Nd- and O-isotopic compositions indicate an origin from crustal melting (Trumbull et al., 2000; 2004). The other samples represent tourmalines from the country rocks of the Erongo granite, which comprise Neoproterozoic pelitic schists and Cambrian Stype granites. London (1999) argued that the source for B-rich granitic magmas capable of crystallizing tourmaline must itself be rich in boron, and he also predicted that tourmaline-bearing rocks are the most likely to meet these conditions. It is reasonable to suspect that the tourmalinebearing lithologies in the Damara basement were the source of boron in the Erongo magmas and the basement samples were analyzed to test this hypothesis. 
The occurrence of tourmaline in the Erongo granite is of special interest because it forms distinctive orbicular segregations with quartz. Such tourmaline-quartz segregations are known from several other boron-rich granites (e.g., Schust et al., 1970; Sinclair and Richardson, 1992; Taylor et al., 1992; Trumbull, 1993; Rozendaal and Bruwer, 1995; London, 1999; Jiang et al., 2003). Their origin is still not well understood, but it has been suggested that unmixing of a boron-rich late magmatic/early hydrothermal fluid from evolved granitic magma is involved (Samson and Sinclair, 1992; Taylor et al., 1992). The nature of this fluid, whether a volatile-rich residual melt or high-temperature aqueous liquid, is difficult to determine for lack of direct evidence in the rocks. Because of the expected fractionation of ${ }^{11} \mathrm{~B}$ and ${ }^{10} \mathrm{~B}$ between aqueous fluid and granitic melt (Hervig et al., 2002), the Bisotopic composition of tourmaline can help understand the nature of the fluid(s) from which it formed.

\section{Geologic setting}

The Neoproterozoic Damara Belt comprises a thick sequence of metapelitic and metacarbonate rocks that were deposited in an intracontinental rift setting between the Kalahari and Congo Cratons, then multiply deformed, regionally metamorphosed and partially melted during compressional orogeny as the rift closed (see Miller, 1983 for an overview). The Damara Belt is divided into several tectono-stratigraphic zones, of which the northern Central Zone is the focus of this paper. This sector of the Damara Belt is dominated by upper greenschist-facies pelitic rocks of the Kuiseb Formation, which are interpreted as a former turbidite sequence (Miller, 1983; Steven and Moore, 1995), and by a large number of syn- to post-tectonic S-type granite plutons of early Cambrian age. These Cambrian granites are intrusive into the Kuiseb schists at the present exposure level and are considered to be derived from lithologically similar sources below (Miller, 1983; McDermott et al., 1996; Jung et al., 2003). Associated with the Damara S-type granites are a large number of granitic pegmatites which generally contain abundant tourmaline (Keller et al., 1999 and references therein). Of special relevance for this study is the occurrence of tourmaline-rich zones in the Kuiseb schists, some of which are rich enough in that mineral to classify as tourmalinites (Slack et al., 1984). The Kuiseb tourmalinites have been described by Badenhorst (1988). A more detailed study was made by Steven 
and Moore (1995) in the same area from which our samples were collected (Fig. 1). Their observations of textures and field relations indicate that tourmalinization of the Kuiseb schists is neither directly related to contact metasomatism from the Damara granites and pegmatites, nor is a syn-sedimentary, volcanic-exhalative origin likely. Instead, Steven and Moore (1995) argue that the tourmalinites formed from B-rich late diagenetic basin brines and/or metamorphic fluids derived from the Kuiseb sequence.

The Erongo granite is a late intrusive unit within the largely volcanic Erongo complex, which is one of about 20 subvolcanic ring complexes that were emplaced into the Central Zone during the late Cretaceous (ca. 132-130 Ma: Pirajno et al., 2000; Wigand et al., 2004). Descriptions of the igneous units of the Erongo complex can be found in Blümel et al. (1979), Pirajno (1990), Trumbull et al. (2003) and Wigand et al. (2004). In simplest terms, the complex consists of a deeply-eroded bowlshaped volcanic massif made up of rhyodacitic tuffs overlying andesite-dacite lavas. A resurgent plug of granodiorite, which is identical in composition to the rhyodacite tuffs, is exposed in the low-lying center of the "bowl" (Fig. 1b). The Erongo granite occurs mainly as peripheral intrusions located outside the volcanic massif and it also forms numerous dikes and sills cutting the Erongo volcanic units of the central massif. Most exposures of the granite consist of coarse-grained and equigranular 2mica leucogranite, but there is also a fine-grained facies which occurs in irregular patches and aplitic dikes, and scarce pegmatitic patches or lenses. Very distinctive and characteristic of the Erongo granite are round, tourmaline-quartz orbicules up to $30 \mathrm{~cm}$ in diameter (Fig. 2), which occur in all exposures of the granite including its fine-grained facies. The Ar-Ar and U-Pb ages reported by Wigand et al. (2004) demonstrate that the Erongo granite, along with other major units of the complex, were emplaced at 131 to $130 \mathrm{Ma}$, contemporaneous with the other Damaraland complexes and with the peak phase of flood basalt eruptions in the Etendeka and Paraná provinces.

\section{Analytical methods}

Electron microprobe (EPMA) analyses were performed on polished $2.5 \mathrm{~cm}$ diameter round thin sections using a CAMECA SX-100 instrument at the GFZ Potsdam. Operating conditions were $15 \mathrm{kV}$ accelerating voltage and $10 \mathrm{nA}$ beam current. Natural oxide and silicate mineral reference materials 
were used for calibration and data reduction employed the method of Pouchou and Pichoir (1984; 1985). Tourmaline structural formulae were calculated from the EPMA analyses by normalizing to 15 cations in the tetrahedral and octahedral sites $(\mathrm{T}+\mathrm{Z}+\mathrm{Y})$ assuming stoichiometric $3 \mathrm{~B}$ atoms per formula unit (Henry and Dutrow, 1996). For a limited number of tourmalines we also determined B, Li and $\mathrm{H}$ contents by SIMS (see below) and for these, mineral formulae were calculated assuming 31 total anions $(\mathrm{O}, \mathrm{OH}, \mathrm{F})$.

The samples and analysis sites targeted for SIMS analysis were selected after the EPMA results. The selected samples were repolished with alumina and distilled water to remove the carbon coat, then ultrasonically cleaned with high purity ethanol and coated with a $\sim 35 \mathrm{~nm}$ thick, high-purity gold coat. Boron isotope compositions were measured on 7 samples from the Erongo granite and 5 basement samples using the CAMECA ims6f SIMS instrument at the GFZ Potsdam. In order to minimize sample outgassing within the instrument, samples were stored for several days under high vacuum in a specially designed storage chamber (Wiedenbeck et al., 2004) prior to SIMS analysis. This procedure, in conjunction with the use of a liquid nitrogen cold trap, provided a secondary ion source vacuum in the mid $10^{-8} \mathrm{~Pa}$ range.

Boron isotopic analyses employed a nominally $12.5 \mathrm{kV}, 1 \mathrm{nA}{ }^{16} \mathrm{O}^{-}$primary beam which was focused to a $\sim 5 \mu \mathrm{m}$ spot on the sample surface. Prior to each analysis an unrastered 5 minute preburn was used in order to remove the gold coat and establish equilibrium sputtering conditions. The mass spectrometer was operated at moderate mass resolving power of $\mathrm{M} / \Delta \mathrm{M} \approx 1470$ which is more than adequate for resolving the critical isobaric interference of ${ }^{10} \mathrm{~B}{ }^{1} \mathrm{H}$ on the ${ }^{11} \mathrm{~B}$ mass station as well as the less significant interference of ${ }^{9} \mathrm{Be}{ }^{1} \mathrm{H}$ on ${ }^{10} \mathrm{~B}$. A $150 \mu \mathrm{m}$ diameter contrast aperture, a $750 \mu \mathrm{m}$ field aperture (equivalent to a $60 \mu \mathrm{m}$ field-of-view) and a $50 \mathrm{~V}$ energy window were used without application of a voltage offset. These conditions resulted in a count rate for ${ }^{11} \mathrm{~B}$ of $\sim 250 \mathrm{kHz}$ on the electron multiplier to which a $16 \mathrm{~ns}$ deadtime correction was applied. A single analysis consisted of 50 scans of the peak stepping sequence 0.95 background $(0.1 \mathrm{~s}),{ }^{10} \mathrm{~B}(4 \mathrm{~s})$ and ${ }^{11} \mathrm{~B}(2 \mathrm{~s})$ resulting in a total analysis time of 11 minutes including preburn. The combined instrumental and matrix-induced isotopic fractionation was calibrated using tourmaline reference dravite (Harvard mineral collection \#108796), schorl (\#112566) and elbaite (\#98144) described by Dyar et al. (1998; 2001). Instrumental 
mass fractionation (IMF) was monitored by 3-5 daily measurements on each of the reference tourmalines during the analytical session. Significant drift was noted in the IMF values during the twoweek period of analyses and this was accounted for by correcting measured data using the IMF values determined on a daily basis (see Table 2 for a typical example). The similarity of IMF values (Table 2) determined for the chemically distinct tourmaline standards demonstrates a lack of significant chemical matrix effect with our analytical setup. The observed internal precision for individual analyses $(1 \sigma /$ mean for 50 cycles) was typically $0.5 \%$ to $0.8 \%$ and the external reproducibility $(1 \sigma /$ mean for repeated analyses of reference tourmalines) was less than $1.5 \%$. The reported $\delta^{11} \mathrm{~B}$ values were calculated relative to NIST SRM 951 as $\delta^{11} \mathrm{~B}=$ zero, using a ${ }^{11} \mathrm{~B} /{ }^{10} \mathrm{~B}$ ratio of 4.04362 (Catanzaro et al., 1970). Based on a comparison of measured and determined $\delta^{11} \mathrm{~B}$ values for the reference tourmalines we believe our analyses are accurate within about $1.7 \%$ (Table 2).

In order to achieve a complete characterization of tourmaline compositions for a selection of representative samples, we supplemented the EPMA data by conducting $\mathrm{H}, \mathrm{Li}$ and B concentration analyses by SIMS. The operating conditions were identical to those used for the boron isotopic work, the one exception being that the mass spectrometer was operated at $M / \Delta M \approx 2750$. A single analysis consisted of 20 scans of the peak stepping sequence 0.95 background $(0.1 \mathrm{~s}),{ }^{1} \mathrm{H}(2 \mathrm{~s}),{ }^{7} \mathrm{Li}(4 \mathrm{~s}),{ }^{11} \mathrm{~B}(2$ s) and ${ }^{30} \mathrm{Si}(4 \mathrm{~s})$, resulting in a total analysis time of 11 minutes. Instrument calibration employed the same three tourmaline reference materials from Dyar et al. (2001).

All of the 100 tourmaline analyses including B-isotopic ratios are presented in the electronic appendices A and B, and Table 1 gives representative analyses. The full set of ca. 300 microprobe analyses of tourmaline is available from the authors on request.

\section{Sample selection and tourmaline petrography}

In the descriptions that follow, the tourmaline coloration refers to colors in thin section. All of the tourmalines referred to appear black in hand specimen. 


\section{$\underline{4.1 . ~ E r o n g o ~ g r a n i t e ~}$}

Samples of the Erongo granite were collected from outcrops in two localities, one on the southern margin of the complex and the other on its northwestern margin (Fig. 1b). These samples include tourmaline from the tourmaline-quartz orbicules (samples ER2, ER3, ER198, ER201, ER211) as well as interstitial accessory grains in the granite matrix (samples ER200, ER210, ER369). The tourmaline-quartz orbicules are distinctive, round, black bodies several $\mathrm{cm}$ to $10 \mathrm{~s}$ of $\mathrm{cm}$ in diameter which are distributed randomly throughout the outcrops (Fig. 2a). Tourmaline from the orbicular segregations forms anhedral poikilitic grains intergrown with rounded, locally euhedral equigranular quartz and with relict grains of partly replaced perthitic K-feldspar and plagioclase near the orbicule margins (Fig. 2b). Point-counting analyses on polished rock slabs yielded estimated proportions of 41 to 48 vol. $\%$ of tourmaline in the orbicules ( 3 samples counted, $700-1000$ points each). Other minerals in the orbicules were not point-counted but they are almost entirely quartz, with very minor fluorite, relict microcline and plagioclase feldspar, and secondary white mica. Some of the orbicules are surrounded by a light halo in the granite which is caused by a drop in the abundance of biotite (Fig. 2a). The physical nature of the Erongo quartz-tourmaline orbicules is very similar to those described from the Seagull batholith of Yukon, Canada (Samson and Sinclair, 1992; Sinclair and Richardson, 1992). Like them, the Erongo orbicules form physically separate, discrete bodies within the granite with no evidence of any connections outward by veining or otherwise. This implies that whatever the process of formation was, it took place within the granite and without important influx from external materials. Also important to note is the common observation of plagioclase and K-feldspar relicts partially replaced by tourmaline and quartz within the orbicules. This attests to quartz-tourmaline growth late in crystallization history and at the expense of previously-formed minerals.

The orbicular tourmalines are colored in various shades of olive-brown to tan in thin section, with interior patches, irregular rims, or cross-cutting veinlets of light to dark blue color (Fig. 3a, 3c). The distribution of color zoning within tourmaline grains and grain aggregates is quite variable and can be oscillatory; in most cases the brown tourmaline forms the interior parts of the grains and is surrounded by lighter tan or blue tourmaline. Locally, the relationship between brown and blue tourmaline correlates with successive generations of growth, as where dark blue tourmaline forms 
sharp overgrowths on brown tourmaline, or where blue tourmaline fills cross-cutting fractures within brown tourmaline and intervening quartz (Fig. 3c).

Tourmaline also occurs as minor accessory grains in the Erongo granite outside the tourmalinequartz orbicules. Two different types of accessory tourmalines were recognized. One type forms as subhedral to euhedral, zoned grain aggregates replacing feldspar, which appear much like the orbicules but are smaller and less regular in shape (sample ER211). The other type occurs as interstitial fillings between quartz grains. In one example (Fig. 3d-1), the interstitial tourmaline forms a radiating cluster or "spray" of fine acicular grains and in another (Fig 3d-2) interstitial tourmaline appears as a massive, anhedral filling.

\subsection{Basement samples}

Tourmalinites from the Kuiseb Formation were sampled at two localities in the Central Damara Belt. Four of the five samples were collected from outcrops of Kuiseb schist and early Cambrian granites $\left(15^{\circ} 40^{\prime} \mathrm{E}\right.$ and $21^{\circ} 15^{\prime} \mathrm{S}$, Fig. 1a,c) in an area about $30 \mathrm{~km} \mathrm{NW}$ of the Erongo granite. Steven and Moore (1995) have described the geologic and petrographic characteristics of tourmalinites at this locality in detail. The metamorphic rocks are quartz-muscovite-biotite-cordierite schists which typically show lamination or banding of former pelitic and psammitic layers. The modal tourmaline abundance is highest in the pelitic layers and reaches an estimated 50-70 vol. \% locally. The Kuiseb schists are intruded by several plutons of biotite granites, granodiorite and leucogranites and by abundant pegmatite dikes. Three of our tourmalinite samples (2585-1, 2583-6 and 2588-6) correspond to Steven and Moore's (1995) tourmalinite type 1 (finely-bedded, foliation-conformable). Tourmaline in these samples is very fine-grained (10-100 micron length), subhedral-granoblastic and commonly forms grain aggregates. The color is strongly pleochroic from light tan to olive-brown and there is no color zoning. Apart from quartz, the other minerals in these samples are opaque phases, some of which are leucoxene and others graphite. The fourth sample (248-8) represents a medium-grained quartztourmaline rock with about 50 vol. \% tourmaline. Tourmaline forms subhedral prismatic crystals and grain aggregates which, in contrast to the other samples, are generally not aligned parallel with the banding but show more random orientations. Two quartz-albite-tourmaline pegmatites were sampled 
for this study (2682-1 and 248-4) but SIMS boron-isotope data were obtained only from the former. The pegmatitic tourmalines are subhedral, fragmented prismatic grains with light to dark blue (sample 248-4) or olive-brown to blue absorption colors (sample 2682-1). Internal patchy color variations are common but there are no regular zoning patterns.

The second locality of Kuiseb tourmalinite differs from the first in being free of granitic and pegmatite intrusions. It is located about $150 \mathrm{~km} \mathrm{SSE}$ of the first, at about $16^{\circ} 15^{\prime} \mathrm{E}, 22^{\circ} 40^{\prime} \mathrm{S}$, in the Khomas "hochland" (see Kukla, 1992 for geologic description). Sample 391a from this locality is a fine-grained, banded muscovite-biotite-garnet-staurolite schist with about 10 vol.\% tourmaline. Tourmaline forms short, prismatic euhedral crystals of 100-500 microns length. The light tan to olivegreen tourmaline crystals are mostly unzoned, although some contain small rounded, darker cores that may be detrital in origin. Unfortunately, these cores are too small to measure with SIMS.

\section{Chemical composition of tourmalines}

\subsection{General observations}

Nearly all of the ca. 300 tourmaline analyses obtained in this study fall within the alkali group in the nomenclature of Hawthorne and Henry (1999) with very low Ca contents and moderate X-site vacancies. The few exceptions to this have more than $50 \%$ vacancies in the $\mathrm{X}$ site, and thus correspond to the "vacancy group". Nearly all the tourmaline analyses plot on the Al-rich side of the schorl-dravite join in the total Al-Fe-Mg ternary diagram of Henry and Guidotti (1985), whereby tourmalines from granite and pegmatite samples cluster at high $\mathrm{Fe} / \mathrm{Mg}$ ratio and those from the basement metasediments plot at intermediate $\mathrm{Fe} / \mathrm{Mg}$ values (Fig. 4). It has often been shown that the major element composition of tourmaline is strongly influenced by the host rock composition (Henry and Guidotti, 1985), and this appears to be the case in the present study as well. Tourmaline from the Erongo granite and Damara pegmatites can be discriminated completely from those in metasedimentary hosts in terms of their $\mathrm{Fe} /(\mathrm{Fe}+\mathrm{Mg})$ and $\mathrm{Na} /(\mathrm{Na}+\mathrm{Ca})$ ratios (Fig. 5a). The range of $\mathrm{Ti}$ concentration is similar in both hosts (Fig. 5b) whereas F contents are considerably higher in the granite-hosted samples than the basement tourmalines (Fig. 5d). It is important to note that the high $\mathrm{Al}$ contents, in excess of the 6 cations per formula unit (pfu) for ideal schorl-dravite, are not related to the 
elbaite exchange component ( $\left.\mathrm{AlLiFe}_{-2}\right)$ because Li concentrations in all samples analyzed by SIMS are very low $\left(<0.01\right.$ wt. $\% \mathrm{Li}_{2} \mathrm{O}$, Table 1$)$. Alternative substitutions that can increase the content of octahedral Al involve either alkali site vacancies $\left(\mathrm{Al}, \square(\mathrm{Na}, \mathrm{Fe})_{-1}\right.$; the foitite exchange component $)$ or $\mathrm{O}$ for $\mathrm{OH}$ substitution $\left(\mathrm{AlOHO}_{-1}\right.$; the olenite exchange component) or, finally, exchange with ferrous iron $\left(\mathrm{AlFe}^{3+}{ }_{-1}\right)$. There is a strong linear correlation between the proportion of $\mathrm{X}$-site vacancy and the total $\mathrm{Al}$ concentrations in tourmaline, with a slope of 1 , confirming the importance of the foitite substitution (Fig. 5c). Some samples deviate from the foitite trend and show increasing Al with no change in X-site vacancy. Those samples lack the negative correlation of $\mathrm{Al}$ with Fe that would result from the exchange component $\mathrm{AlFe}_{-1}$, and it is likely that the high $\mathrm{Al}$ contents are charge-balanced by the $\mathrm{OH}-\mathrm{O}$ substitution.

Recent attention has been paid to the presence of "excess" boron in tourmaline( $>3$ cations pfu), which substitutes for Si in tetrahedral sites (Hughes et al., 2001; Marschall et al., 2004; Ertl et al., 2006). This can be significant for boron isotope behavior, since isotopic fractionation depends on the coordination environment of boron (see section 7.1). To check for tetrahedral boron in our study, tourmaline formulae were calculated based on 31 anions for analyses that included SIMS values for B, $\mathrm{Li}$ and $\mathrm{H}$ concentrations. Several samples have greater than $3 \mathrm{~B}$ cations per formula unit, the maximum being 3.3 (Appendix A, B). However, there is no correlation between Si and B to suggest that the "excess" boron occupies tetrahedral sites and in fact, some of the samples with "excess" B also have greater than the stoichiometric $6 \mathrm{Si}$ cations pfu. Without crystallographic study of the samples we cannot rule out or confirm the presence of tetrahedral boron but we consider it likely that much of excess B results from accumulated analytical errors propagated in the mineral formula calculations, as mentioned by Dyar et al. (1998).

\subsection{Tourmalines in the Erongo granite}

We distinguish three groups of tourmaline in the Erongo granite. Group 1 comprises the predominant, main-stage consisting of brown-tan orbicular tourmaline intergrown with quartz. Group 2 are late-stage tourmalines from within the orbicular segregations, occurring either as rims on zoned crystals, generally light tan or bluish in color, or as replacement veinlets of bluish color that cross-cut 
group 1 tourmaline (Fig. 3c). Group 3 tourmalines are isolated grains or grain aggregates in the granite matrix, which occur as vein-fillings or in grain intersticies. It is important to emphasize that tourmaline in the granite is almost exclusively of the group 1 type and also, that the interstitial grains in the granite matrix are either clearly secondary or of ambiguous origin. In other words, there is no clear evidence for magmatic tourmaline having formed outside the quartz-tourmaline orbicules and if any of the matrix tourmaline is primary, the volume is vanishingly small.

The orbicular, main-stage tourmalines (group 1) have a compositional range of $\mathrm{Fe} /(\mathrm{Fe}+\mathrm{Mg}$ ) between 0.8 and 1.0 and $\mathrm{Na} /(\mathrm{Na}+\mathrm{Ca})$ between 0.95 and 1.0 (Fig. 5a). The $\mathrm{F}$ and $\mathrm{TiO}_{2}$ contents vary over a wide range ( 0.1 to 1.5 wt. $\%$ and 0 to 1.9 wt.\%, resp.). Group 1 tourmalines are distinguished by having the highest values of $\mathrm{TiO}_{2}$ in this study (Fig. 5b). As described in the section on zoning below, Ti appears to be the main control for the intensity of brown color in thin section. The group 1 tourmalines are Al-rich compared to ideal schorl-dravite, with total Al contents between 6 and 6.8 cations per formula unit, and the show considerable alkali-deficiency (X-site vacancies up to $50 \%$ ). The late-stage, group 2 tourmalines from the orbicules overlap in composition with group 1 tourmalines in most respects (Fig. 5a-d), but some group 2 grains have higher values of alkali deficiency (58-69\% X-site vacancies in sample ER211). The group 3, interstitial tourmaline grains are Fe-rich like groups 1 and 2, with $\mathrm{Fe} /(\mathrm{Fe}+\mathrm{Mg})$ ratios from 0.8 to 1 , and they also have the same range of $\mathrm{F}$ and $\mathrm{TiO}_{2}$ concentrations as the other groups (Fig. 5b, d). However, many group 3 tourmalines have higher $\mathrm{CaO}$ contents than the other tourmaline groups, and a corresponding greater range in $\mathrm{Na} /(\mathrm{Na}+\mathrm{Ca})$, from 1 to 0.85 . Group 3 tourmalines are also among the most Al-rich, with up to 7.8 cations per formula unit for interstitial granis from sample ER210 (Fig. 5c).

\subsection{Correlations of tourmaline color zoning and composition}

Most of the tourmalines from the Erongo granite, particularly those from quartz-tourmaline orbicules, show distinct color variations, which can be patchy or follow regular growth zoning. The patterns of color variations can be highly complex and tourmaline coloration has not been studied in detail. However, color zoning is useful as a guide to the sequence of crystal growth, overgrowths and internal replacements, and these features were important for selection of points for B-isotope analyses. 
Compositional profiles are illustrated in Fig. 6 for tourmaline grains which show prominent growth zoning and which were selected for B-isotope analyses (samples ER3, ER210 and ER211). The positions of SIMS analyses are indicated by open circles along the profiles and the corresponding $\delta^{11} \mathrm{~B}$ values are given above each plot. The results are discussed in the following section.

In sample ER210, the zoning between darker brown-olive and tan-bluish tourmaline is oscillatory. The bluish and light brown tourmaline at the core has the lowest $\mathrm{Ti}$ and $\mathrm{Mg}$ contents in the profile. The main chemical variations across the lighter and darker tourmaline zones are in $\mathrm{Mg}$ and $\mathrm{F}$ contents, which tend to correlate with each other and are higher in the lighter-colored zones and the rim. Iron and Al contents are nearly constant across the profile. The oscillatory zoning in sample ER3 involves alternating bands of dark brown vs. light brownish-blue tourmaline (Fig. 3a). The chemical variations in this profile are mainly in $\mathrm{Mg}$ and $\mathrm{Ti}$, which correlate well with each other and are both lower in the ligher brown-bluish zones. Sample ER211 is characterized by a simpler zoning pattern with olive-brown core and light tan-blue rim (Fig. 3b). As in the other grains, the darker brown tourmaline has higher Ti contents and there is a good positive correlation in this case between $\mathrm{Ti}, \mathrm{Mg}$ and $\mathrm{F}$ contents, with all three dropping strongly at the core-rim boundary. This sample differs from the others in that the $\mathrm{Al}$ contents are also zoned, with an overall increase from core to rim.

\subsection{Basement samples}

The major element composition of tourmalines from Damara pegmatites, samples 248-4 and 2682-1, are in the mid-range of Erongo orbicular tourmalines, with 0.83 to 0.97 $\mathrm{Fe} /(\mathrm{Fe}+\mathrm{Mg})$, total $\mathrm{Al}$ contents of 6.5 to 6.7 cations per formula unit and $30-40 \% \mathrm{X}$-site vacancy (Fig. 5a,c). The $\mathrm{TiO}_{2}$ and $\mathrm{F}$ contents are in the range 0.1 to $0.75 \mathrm{wt} . \%$ and 0.1 to 0.8 wt.\%, respectively (Fig. 5b,d). Tourmalines from the Damara metasediments are distinct from the granite/pegmatite tourmalines. They are more magnesian $(\mathrm{Fe} /(\mathrm{Fe}+\mathrm{Mg})=0.3$ to 0.6$)$ and more calcic $(\mathrm{Na} /(\mathrm{Na}+\mathrm{Ca})=0.65$ to 0.9$)$. They have a similar range of $\mathrm{TiO}_{2}$ concentrations (0.2 to 1.3 wt. $\%$ ) as the granitic tourmalines but less fluorine ( 0 to 0.5 wt.\%). The metasediment tourmalines are also less aluminous than the granitic tourmalines, and a few 
analyses yielded slightly less than 6 cations total Al per formula unit (range 5.9 to 6.5). Correspondingly, the degree of alkali-deficiency is lower than in granitic tourmalines, with 15 to $30 \% \mathrm{X}$-site vacancies in most samples, and outliers to $45 \%$ (Fig. $5 \mathrm{c}$ ).

\section{Boron isotope compositions}

The total range in boron isotope compositions determined in our sample suite, expressed as $\delta^{11} \mathrm{~B}$ values relative to NIST SRM 951, is from $-11.6 \%$ to $-1.3 \%$ for the Erongo granite tourmalines and from $-13.4 \%$ to $-6.7 \%$ for tourmalines from the Damara basement rocks (Fig. 7). The overall isotopic variation of Erongo tourmalines is quite large but in detail, different tourmaline groups show smaller ranges and some systematic differences. The Erongo group 1 (orbicular) tourmalines have a narrow range of $\delta^{11} \mathrm{~B}$ values, with a mean of $-8.7 \% \pm 1.5(\mathrm{n}=49)$, consistent with a nearly homogeneous population considering our analytical uncertainties of about $1.5 \%$. Late-stage tourmaline from the orbicules (group 2) is isotopically heavier on average and more variable than group $1\left(\delta^{11} \mathrm{~B}=-5.8 \% \mathrm{t}\right.$ $3.1, \mathrm{n}=22$ ). More important, the group 2 tourmalines have a bimodal distribution of $\delta^{11} \mathrm{~B}$ values (Fig. $7 b)$, with one peak overlapping the mid-range of group $1(-9 \%)$ and a second peak at much heavier values $(-3 \%)$. The average $\delta^{11} \mathrm{~B}$ value for interstitial tourmalines from the matrix granite (group 3) is $7.3 \% \pm 3.2(\mathrm{n}=15)$, and in detail this group also shows a bimodal distribution, with several values around $-9 \%$ and others in the range -4 to $-1 \%$. There are no systematic correlations between B-isotope ratios and chemical composition of the tourmalines, at least in terms of the major elements analyzed. Boron isotope variations in zoned crystals were systematically sought for in crystals large enough for multiple SIMS analyses. Most tourmaline grains were found to lack significant isotopic zoning but important exceptions were found in two samples, ER210 and ER211 (Fig. 6b,c,d). In both of these samples, isotopically zoned tourmaline occurs as euhedral grains growing at the margins of larger tourmaline-quartz segregations, i.e., at the interface with the granite matrix (Fig. 3b,e). The outer growth zones of these grains are enriched in ${ }^{11} \mathrm{~B}$ relative to the grain interiors, the latter showing the "normal" range of $\delta^{11} \mathrm{~B}$ values near $-10 \%$. The isotopic contrast between rim and core can be abrupt. In the grain shown in Figure $3 b$ there is a variation of 5\%o over a distance of 10-20 microns (Fig. 6d). It is worth noting that the ${ }^{11} \mathrm{~B}$-rich tourmaline rims in these examples are light in color compared with 
the grain interiors, but there is no systematic relationship of color and chemical variations of tourmaline in these samples with their isotopic composition (compare Fig. 3a and 6a).

Far fewer analyses of boron isotopic composition were obtained from tourmalines in samples of the Damara basement rocks (Table 1, Appendix B, Fig. 7b). The average $\delta^{11} \mathrm{~B}$ value is $-9.2 \% \pm 2.3$ $(n=13)$, which is very similar to that of the main-stage tourmalines from the Erongo granite. When the host-rock lithologies are treated separately, their average values are statistically the same, with $\delta^{11} \mathrm{~B}=$ $-9.2 \%_{0} \pm 2.4$ for the Kuiseb metasediments and $\delta^{11} \mathrm{~B}=-8.4 \% 0 \pm 0.9$ for the Damara pegmatite. An important difference between the Damara basement tourmalines and those from Erongo is that none of the basement tourmalines yielded $\delta^{11} \mathrm{~B}$ values heavier than $-6 \%$ o (Fig. 7). The basement tourmaline grains are generally not zoned optically and no isotopic variations from core to rim were found although as mentioned above, most tourmaline grains from metasediments were too small to measure rim and core compositions separately. In summary, the isotopic composition of boron from tourmalines in the Damara metasedimentary and granitic (pegmatite) basement rocks is essentially the same as the composition in the main-stage tourmalines from the Erongo granite. This is consistent with other evidence that the Erongo magmas were derived from partial melting of Damara crustal rocks (Trumbull et al., 2004), as discussed in more detail in the following section.

\section{Discussion}

\section{$\underline{\text { 7.1. Boron isotope fractionation among tourmaline, fluids and granitic melts }}$}

Before interpretating the observed boron isotope variations in tourmalines with respect to magmatic and/or hydrothermal processes, some discussion is needed on the nature and extent of isotopic fractionation to be expected between tourmaline and the fluids or melts involved. In principle, the partitioning of ${ }^{11} \mathrm{~B}$ and ${ }^{10} \mathrm{~B}$ between coexisting phases depends on the coordination environment of boron within them and the isotopic fractionation factor is also temperature and pressure dependent (Palmer et al. 1992; Palmer and Swihart, 1996; Williams et al. 2001; Hervig et al. 2002; Wunder et al., 2005). It is well established that boron in aqueous fluids of low $\mathrm{pH}$ that are suitable for tourmaline stability occurs in trigonal $\mathrm{B}(\mathrm{OH})_{3}$ complexes (Palmer and Swihart, 1996), and Raman spectroscopy in diamond anvil cell experiments confirm the dominance of trigonal coordination at high temperatures 
and pressures (Schmidt et al., 2005). Boron in tourmaline also occurs almost exclusively as trigonal $\mathrm{BO}_{3}$ groups although cases of tourmaline have been reported with minor amounts of "excess" boron ( $>3$ cations pfu) that was shown to occupy tetrahedral sites in place of Si (e.g., Hughes et al. 2001; Marschall et al. 2004; Ertl et al., 2006). As mentioned above, our chemical analyses of tourmaline show some "excess" B, but no convincing evidence that this is in tetrahedral sites.

Palmer et al. (1992) found significant B-isotope fractionation between tourmaline and water in exchange experiments, which was unexpected since the boron coordination is trigonal in both aqueous fluids and tourmaline. They postulated that the fractionation was due to isotope exchange between boron in the fluid and pseudo-tetrahedral surface complexes on the growing tourmaline. Another possible explanation for the observed fractionation comes from work by Liu and Tossell (2005), who pointed out that the calculated $\mathrm{B}-\mathrm{O}$ bond energies of $\mathrm{B}(\mathrm{OH})_{3}$ or $\mathrm{B}(\mathrm{OH})_{4}$ complexes in aqueous solution are different from those of $\mathrm{BO}_{3}$ or $\mathrm{BO}_{4}$ in silicates, with the result that the boron silicates will be enriched in the lighter ${ }^{10} \mathrm{~B}$ isotope relative to the fluid.

The speciation and coordination environment of B in natural granitic melts are subject to many influences and can be quite variable. Dingwell et al. (1996) reviewed studies on the behavior of boron in synthetic and natural melts and the effects of alkali elements, aluminum and water on boron speciation. Studies of anhydrous borosilicate glasses $\left(\mathrm{Na}_{2} \mathrm{O}-\mathrm{SiO}_{2}-\mathrm{B}_{2} \mathrm{O}_{3}\right)$ showed an increase in the proportion of boron in tetrahedral sites with increasing alkali contents, whereas adding aluminum and silica reverses this trend as those components compete for tetrahedral sites. Natural melts capable of crystallizing tourmaline are hydrous and there is a positive feedback between increased B contents and higher solubility of water in granitic melts (London, 1992). Such melts are often commonly enriched in other volatile elements like $\mathrm{F}$ and $\mathrm{Li}$, adding complexity to the melt structure and the issue of boron speciation. Both trigonal and tetrahedral boron complexes occur in natural granitic melts (Dingwell et al., 1996) but there is currently no way to predict their proportion for a given composition. Direct determination of boron speciation in natural melts are not abundant. A reconnaissance study by Morgan et al. (1990) found mostly trigonal B complexes in hydrous Na-Al borosilicate melt and Thomas et al. (2003) determined trigonal coordination of boron in extremely water-rich melt inclusions. In an important NMR study of natural rhyolitic glasses, Tonarini et al. (2003) found 
significant amounts of both trigonal and tetrahedral boron complexes, with the former predominating. Indirect evidence for significant tetrahedral coordination of boron in evolved granitic melts is given by the study of B-isotope exchange between melt and aqueous fluid by Hervig et al. (2002). That study is especially relevant to the present paper because the experiments used natural Macusani rhyolite, which has a hydrous, peraluminous, F- and B-rich composition similar to that of the Erongo granite. The results showed significant melt/fluid isotopic shifts $\left(7.1 \%\right.$ at $750^{\circ} \mathrm{C}$ and $4.4 \%$ at $\left.850^{\circ} \mathrm{C}\right)$, implying a change in B coordination between the fluid (trigonal) and melt. Also, the fluid/melt fractionation factors of Hervig et al. (2002) plot on the same linear trend with reciprocal temperature as those of mineral-fluid experiments where B is known to shift from trigonal (fluid) to tetrahedral coordination (see Wunder et al., 2005).

Many empirical studies of B-isotopes in tourmaline from igneous and metamorphic rocks and from hydrothermal veins found significant variations in $\delta^{11} \mathrm{~B}$ between early and late tourmaline generations, sometimes in single zoned crystals, which were interpreted in terms of temperaturedependent isotopic fractionation during crystal growth (Smith and Yardley, 1996; Chaussidon and Appel, 1997; Jiang and Palmer, 1998; Nakano and Nakamura, 2001; Matthews et al., 2003; Jiang et al., 2003; this paper). However, there are also examples of isotopic homogeneity in zoned or polyphase tourmaline growths that argue against significant fractionation effects (Tonarini et al., 1998; Marschall et al., 2006). Clearly, there is a need for more experimental determinations of B-isotope exchange behavior between tourmaline, fluid and melts, and for more spectroscopic determinations of B coordination in granitic melts. However, based on the evidence and arguments presented above we can assume that a considerable proportion of boron in the Erongo magma was in tetrahedral coordination and that some isotopic fractionation is therefore expected between the magma and an exsolved aqueous fluid, or between magma and the tourmaline crystallizing from it. Lacking any direct experimental studies on B-isotope partitioning between tourmaline and granitic melts, we can best estimate a melt-tourmaline fractionation factor by combining experimental fractionation factors for tourmaline-water from Palmer et al., (1992) and melt-water from Hervig et al. (2002). When this is done, and assuming a near-solidus temperature of $650^{\circ} \mathrm{C}$ to be realistic for the near-solidus Erongo 
magma, the result is a predicted isotopic shift of about 5\% between tourmaline and granitic melt, with tourmaline being preferentially enriched in ${ }^{10} \mathrm{~B}$.

\subsection{Implications for the boron source of the Erongo granite}

Analyses of tourmaline from the 4 samples of Damara metapelites at two localities and one pegmatite sample gave an overall range in $\delta^{11} \mathrm{~B}$ values of $-13.4 \%$ to $-6.7 \%$ (average $-9.2 \%$ o $n=13$ ). The data coverage is clearly too small for a complete picture of B-isotope composition of the Damara basement, but at a reconnaissance level we consider it significant that the range and average of $\delta^{11} \mathrm{~B}$ in the basement tourmalines are nearly the same as those of the main-stage tourmalines in the Erongo granite (Fig. 7). On that basis, and considering that the Sr-, Nd- and O-isotope composition of the Erongo granite also require a metasedimentary source (Trumbull et al., 2004), we believe that the boron in the late Cretaceous Erongo tourmalines was derived from the Neoproterozoic Damara basement. This conclusion is unaffected by the predicted ca. 5\% isotopic fractionation between tourmaline and melts because in both the anatexis and crystallization processes, tourmaline will be in contact with a hydrous granite melt at near-solidus temperatures, so the isotopic shift between tourmaline and melt composition in both events should be nearly the same.

\subsection{B-isotope variations within the Erongo granite and origin of orbicular tourmaline}

The important features of B-isotope results for the Erongo granite that need to be explained in an interpretative model can be summarized as follows. The bulk of tourmaline in the Erongo granite (group 1), which forms orbicular segregations with quartz, has a narrow range of $\delta^{11} \mathrm{~B}$ values between about -11 and $-6 \%$ ( 46 of 49 analyses). The other 3 analyses yielded considerably heavier values (-3 to $-5 \%$ ). Of the late-stage tourmalines from group 2 (veins and overgrowths in orbicules) and group 3 (interstitial in the granite matrix), about half of the analyses fall in the same range of $\delta^{11} \mathrm{~B}$ as group 1, whereas the other half is consistently and significantly heavier $\left(\delta^{11} \mathrm{~B}=-1\right.$ to $-4 \%$ ). Furthermore, the distribution of boron isotope ratios within the data set shows two distinct clusters (Fig. 7a), and given the large number of analyses, we consider this bimodal distribution to be a robust feature. The shift in 
composition between isotopically light and heavy tourmaline is particularly vivid in the examples of zoned single crystals from samples ER210 and ER211 (Fig. 6c,d).

Variations in the B-isotope composition of tourmalines from the Erongo granite could potentially result from multiple sources of boron, each with different isotopic composition, or from a single source of boron undergoing an isotopic fractionation process. Considering the first hypothesis of multiple boron sources, a likely scenario for the subvolcanic Erongo intrusion would be mixing of magmatic boron from the granite system with external boron introduced via fluid circulation in the wall-rocks. In this scenario, the group 1 orbicular tourmalines with uniform isotopic composition of about $-9 \%$ would represent the magmatic source whereas the less common and isotopically heavy late-stage tourmalines in veinlets, overgrowths and grain boundaries would reflect the external fluid. We consider it unlikely that external fluids played a significant role for several reasons. First there is no petrographic evidence suggesting infiltration of a B-rich fluid from the wall-rocks. It is true that late-stage tourmalines commonly occur in healed cracks that cut earlier tourmaline and quartz (Fig. 3c) but these features are local and have typical length scales of a few centimeters at most. Another point is that external fluids are not likely to be boron-rich since tourmaline, which is present as the main host of boron in the country rocks, is highly resistant to alteration and dissolution by hydrothermal fluid. Finally, the isotopically heavy tourmalines have no distinct chemical features relative to other tourmalines, such as higher $\mathrm{Mg}$ or $\mathrm{Ca}$ contents, or lower $\mathrm{F}$, as might be expected if they formed from external fluids equilibrated with the country rocks.

The alternative explanation to multiple boron sources is a fractionation of ${ }^{11} \mathrm{~B}$ and ${ }^{10} \mathrm{~B}$ during magma evolution, and this implies a phase separation and exchange between fluid(s) and melt(s) with contrasting boron coordination. As discussed above, fluid exsolution and B-isotope fractionation between silicate melt and aqueous fluid is likely to produce a significant enrichment of ${ }^{10} \mathrm{~B}$ in the residual melt and of ${ }^{11} \mathrm{~B}$ in the fluid, and this process has been proposed to explain $\mathrm{B}$-isotope variations observed in magmatic and hydrothermal tourmalines by Smith and Yardley (1996), Trumbull and Chaussidon (1999) and Jiang et al. (2003). However, there are problems applying the hypothesis to the Erongo tourmalines because the scenario of melt differentiation and exsolution of aqueous fluid seems inconsistent with the nearly exclusive occurrence of tourmaline in the granite as 
discrete tourmaline-quartz orbicules. These orbicules are texturally isolated bodies within the granite, more or less evenly distributed at the outcrop scale and with no visible connection to their surroundings either in outcrop or thin section. We concur with Sinclair and Richardson (1992) and Samson and Sinclair (1992) that formation of the orbicules must involve pluton-internal processes related to magma evolution and rule out formation from infiltrating fluid. Furthermore, it seems inconceivable that the orbicules would form if magma evolved as a single, increasingly differentiated melt phase. Apart from the difficulty of explaining the spatial segregation of spherical bodies by this process, there is the compositional problem that the orbicules consist of about 40 modal percent tourmaline and thus have at least $4 \mathrm{wt} . \% \mathrm{FeO}$. The bulk composition of Erongo granite is only about 1.5 wt.\% FeO, and since biotite and Fe-Ti oxides are magmatic phases, Fe should decrease further with advanced differentiation. Even if the boron concentration could increase enough through differentiation to produce the tourmaline-rich segregations, the Fe contents of such a melt would be impossibly low. By a similar argument, an exsolved aqueous fluid may be rich in boron relative to the granitic melt (London et al., 1996), but it would not be expected to contain high Fe concentrations. A mechanism that could account for both the textural and compositional features of orbicular tourmaline segregations is liquid immiscibility in the evolved melt. Veksler et al. (2002a,b) experimentally confirmed the immiscibility of aluminosilicate-rich and water-rich melts in synthetic haplogranite with added $\mathrm{H}_{2} \mathrm{O}, \mathrm{B}$, Li and F. Particularly relevant to our study is the discovery of extreme boron enrichment $\left(5 \mathrm{wt} . \% \mathrm{~B}_{2} \mathrm{O}_{3}\right)$ in one of two immiscible melts trapped as inclusions in quartz from the Ehrenfriedersdorf pegmatite (Thomas et al., 2003). This finding is consistent with the compositional differences of experimental immiscible melt pairs reviewed by Veksler (2004), indicating that the more water-rich, depolymerized melt becomes strongly enriched in $\mathrm{B}, \mathrm{Na}, \mathrm{Fe}$ and $\mathrm{H}_{2} \mathrm{O}$ relative to the starting composition. In terms of orbicule formation, therefore, liquid immiscibility offers a mechanism to sequester and concentrate $\mathrm{B}$ and $\mathrm{Fe}$ together into a water-rich and thus highly mobile melt phase, which would have the ability to percolate through a crystal mush and to coalesce. The hydrous, B-rich immiscible melt phase is expected to be low in Al (Veksler and Thomas, 2002; Veksler et al., 2002; Thomas et al., 2003) and the Al required for tourmaline growth comes from 
replacement of feldspars, relics of which are commonly observed in the margins of quartz-tourmaline orbicules in the Erongo granite.

We suggest that formation of an immiscible B-rich hydrous melt late in the evolution of the Erongo granite best explains the phenomenon of tourmaline-quartz orbicules. The concept is supported by experimental and melt inclusion observations and is illustrated schematically in Figure 8 . It remains to discuss the implications of this scenario for interpretation of the tourmaline B-isotope data. A key point in this discussion is that phase separation in this scenario (L1 - L2 in Figure 8A) takes place before the formation of main-stage orbicular tourmalines from L2 (the B-rich hydrous liquid). We expect all boron in the L2 liquid to be in trigonal coordination based on Raman studies of B-rich hydrous melt inclusions by Thomas et al. (2003). This means that the shift to high ${ }^{11} \mathrm{~B} /{ }^{10} \mathrm{~B}$ ratios in late-stage tourmalines at Erongo cannot be attributed to a process of fluid exsolution because there should be no isotopic fractionation between the postulated B-rich hydrous melt (L2) and an exsolved hydrothermal fluid as both contain trigonal boron complexes. In other words, if L1-L2 immiscibility is invoked to explain the orbicule formation, then phase separation had already taken place before formation of the main-stage tourmalines and the isotopic shift in late-stage tourmaline must reflect a different process. We propose that this process is a Rayleigh-type distillation resulting from the rapid depletion of boron from the hydrous melt by formation of tourmaline orbicules (Fig. 8B). Rayleigh distillation will produce an isotopic shift only if there is appreciable fractionation between the liquid and tourmaline. Boron coordination in the L2 melt and the tourmaline lattice is dominantly trigonal but as described above, experiments of Palmer et al. (1992) showed there can be significant isotopic fractionation between aqueous fluid and tourmaline. To illustrate the potential effect of the Rayleigh fractionation scenario, model curves were calculated using the Palmer et al. (1992) tourmaline-fluid fractionation factor as well as the factor for complete tetrahedral-trigonal coordination change from Wunder et al. (2005). Both models assumed a temperature of $650^{\circ} \mathrm{C}$ for the near-solidus conditions of volatile-rich granite (lower temperature would increase the fractionation effect). The plots of calculated B-isotope composition in the residual melt versus the fraction of boron remaining (Fig. 9) show that a shift in isotopic composition from average main-stage tourmalines with $-10 \%$ to the heaviest late-stage tourmaline at $-1 \%$ would require between $90 \%$ (tourmaline-water curve) and $70 \%$ 
$\left(\mathrm{B}^{\mathrm{IV}}-\mathrm{B}^{\mathrm{III}}\right.$ curve) removal of boron from the fluid. The isotope shift by Rayleigh fractionation is a continuous process, and the discontinuous distribution of B-isotope ratios in late-stage tourmalines (Fig. 7) can be explained by this process if one postulates that boron depletion took place rapidly in a single episode of tourmaline crystallization. This is consistent with the suggestion that the formation of tourmaline-quartz orbicules was triggered by liquid immiscibility once the requisite degree of differentiation was achieved.

\section{Conclusions}

Tourmaline is an important constituent of the Cretaceous Erongo granite from Namibia and of the basement metapelites and S-type granites of the Damara Belt into which it intruded. Tourmaline in the Erongo granite occurs almost exclusively in the form of orbicular tourmaline-quartz segregations several centimeters to decimeters in diameter, which contain some 40-50 modal percent of tourmaline. The remainder is mostly quartz, with minor relics of K-feldspar and plagioclase that were partially replaced by tourmaline and quartz, and with accessory minerals including fluorite and secondary white mica. The abundant, poikilitic tourmalines from the orbicules (main-stage or group 1 tourmalines) are compositionally intermediate between schorl and foitite, with $\mathrm{Fe} /(\mathrm{Fe}+\mathrm{Mg})$ ratios of 0.8 to 1 and up to $50 \% \mathrm{X}$-site vacancies. The B-isotopic compositions of group 1 tourmalines are quite uniform, both among different samples and within single grains, with an average $\delta^{11} \mathrm{~B}$ value of $-8.7 \%$ \% $\pm 1.5(\mathrm{n}=49)$. Very minor late-stage or secondary tourmaline also occurs in the Erongo granite, either as thin overgrowths on, or veinlets in pre-existing tourmaline from the orbicules (group 2 tourmaline), or as crack-fillings and interstitial grains in the granite matrix (group 3). The chemical composition of the late and secondary tourmaline overlaps that of the main-stage tourmaline but the range is wider and late tourmaline tends toward lower $\mathrm{Fe} /(\mathrm{Fe}+\mathrm{Mg})$ ratios. Some secondary grains have very high $\mathrm{X}$-site vacancies (up to $70 \%$ ). In terms of B-isotope composition the type 2 and type 3 tourmalines show a bimodal distribution, with about half of the analyses falling within the same range of $\delta^{11} \mathrm{~B}$ values as the main stage tourmaline, and the other half at significantly heavier values of -4 to $-1 \%$. The shift from light to heavy isotopic composition can be found in single zoned crystals, wherein a group-1 tourmaline core at $-9 \%$ is overgrown with a narrow rim of group- 2 tourmaline with $-2 \%$. 
Tourmalines from the Damara Belt basement show a strong compositional control by their host rock. Tourmalines from S-type granitic pegmatites have essentially the same chemical composition as the main-stage tourmalines in the Erongo granite, whereas the tourmalinites in metapelite have higher $\mathrm{Mg}$ and $\mathrm{Ca}$ contents, less $\mathrm{Al}$ and less alkali deficiency. The number of B-isotope determinations on basement tourmalines is not enough to characterize them in detail but their overall range (-13.4 to -6.7 $\%)$ and average $\delta^{11} \mathrm{~B}$ values $(-9.2 \pm 2.5 \%, \mathrm{n}=13)$ are very similar to those of the Erongo main-stage tourmalines.

We propose the following scenario for the variations in B-isotope compositions of main-stage and late-stage tourmalines in the Erongo granite, which is closely linked to a hypothesis for the formation of the tourmaline-quartz orbicules. Anatexis of metapelitic and/or peraluminous granites in the Damara basement produced a B-rich granitic melt that later crystallized to form the Erongo granite. Boron in the Erongo magma inherited a $\delta^{11} \mathrm{~B}$ isotopic value of about $-9 \%$ from the crustal source rocks. Boron remained incompatible during ascent and differentiation of the Erongo magma until at a very late stage in crystallization at subvolcanic level, the buildup of water, $\mathrm{B}$ and $\mathrm{F}$ in the melt reached a point where phase separation in the residual melt took place between a highly polymerized aluminosilicate melt and a depolymerized hydrous melt. Boron, $\mathrm{H}_{2} \mathrm{O}, \mathrm{Na}$ and $\mathrm{Fe}$ partitioned preferentially into the latter. The low viscosity and density of the B-rich hydrous melt permitted it to percolate and coalesce within the largely crystalline granite matrix. The strong buildup of $\mathrm{B}, \mathrm{Na}$ and $\mathrm{Fe}$ in the hydrous melt caused rapid crystallization of tourmaline at the expense of preexisting feldspars, creating the orbicular segregations of large, poikilitic tourmaline grains intergrown with quartz. Essentially all of the tourmaline present in the Erongo granite is contained in the tourmaline-quartz orbicules and their quite homogeneous B-isotopic composition of about $-10 \%$ reflects the bulk magmatic value inherited from the Damara crust.

Formation of the tourmaline-quartz orbicules was triggered by liquid immiscibility and the precipitation of tourmaline-rich orbicules throughout the granite at this time caused rapid depletion of boron from the residual hydrous melt. Weak but significant isotope fractionation took place between the tourmaline and hydrous melt, so that boron in the residual fluid became strongly enriched in ${ }^{11} \mathrm{~B}$. We suggest that the very minor, isotopically heavy tourmaline overgrowths on poikilitic grains from 
the orbicules and anhedral interstitial grains, grain clusters and crack-fillings in the granite matrix formed from this residual fluid. Rayleigh fractionation models suggest that about $90 \%$ depletion of boron by tourmaline crystallization would suffice to produce a shift in isotope composition in residual fluid by $8 \%$ relative to the starting composition.

\section{Acknowledgements}

We are very grateful for samples of basement tourmalinites and Damara pegmatites provided by Bernd Bühn from a collection made for a diploma thesis project by Henrik Neuweger at the University of Giessen. Dieter Rhede and Oona Appelt provided expert help with the electron microprobe analyses and Ilona Schäpan gave assistance in the SIMS analyses. We also acknowledge fruitful discussion and debate with Ilya Veksler, Rainer Thomas, Bernd Wunder and Gerhard Franz. Constructive reviews by two anonymous referees led to substantial improvements in clarity of the presentation.

\section{References}

Altherr R, Topuz G, Marschall H, Zack T, Ludwig T (2004) Evolution of tourmaline-bearing lawsonite eglogite from the Elekdag area (Central Pontides, N Turkey): evidence for infiltration of slab-derived B-rich fluids during exhumation. Contrib Min Pet 148: 409-425

Badenhorst FP (1988) A note on stratiform tourmalinites in the Late Precambrian Kuiseb Formation, Damara sequence. Communs Geol Surv SW Africa/Namibia 4: 67-70

Blümel WD, Emmermann R, Hüser K (1979) Der Erongo. Geowissenschaftliche Beschreibung und Deutung eines südwestafrikanischen Vulkankomplexes. Southwest African Scientific Society, Windhoek

Catanzaro EJ, Champion CE, Garner EL, Maienko G, Sappenfield KM, Shields WR (1970) Boric Acid: Isotopic and Assay Standard Reference Materials. National Bureau Standards (US) Spec Publ 260-17, 70 pp

Chaussidon M, Appel PWU (1997) Boron isotopic composition of tourmalines from the 3.8 Ga Isua supracrustals, west Greenland: possible implications on variations of the $\delta 11 \mathrm{~B}$ of seawater in the past. Chem Geol 136: 171-180

Dingwell DB, Pichavant M, Holtz F (1996) Experimental studies of boron in granitic melts. Mineral Soc America, Reviews in Mineralogy 33: 331-385

Dyar MD, Guidotti CV, Dore DP, Wearn KM, Wise MA, Francis CA, Johnson K, Brady JB, Robertson JD, Cross LR (1999) Stable isotope and crystal chemistry of tourmaline across pegmatite-country rocks boundaries at Black Mountain and Mount Mica, southwestern Maine, U.S.A. Eur J Mineral 11: 281-294 
Dyar MD, Taylor ME, Lutz TM, Francis CA, Guidotti CV, Wise MA (1998) Inclusive chemical characterization of tourmaline: Mössbauer study of Fe valence and site occupancy. Am Mineral 83: $848-864$

Dyar MD, Wiedenbeck M, Robertson D, Cross LR, Delaney JS, Ferguson K, Francis CA, Grew ES, Guidotti CV, Hervig RL, Hughes JM, Husler J, Leeman W, McGuire AV, Rhede D, Rothe H, Paul RL, Richards I, Yates M (2001) Reference Minerals for Microanalysis of Light Elements. Geostandard Newslett 25: 441-463

Ertl A, Hughes JM, Prowatke S, Ludwig T, Prasad PSR, Brandstatter F, Korner W, Schuster R, Pertlik F, Marschall H (2006) Tetrahedrally coordinated boron in tourmalines from the liddicaotiteelabite series from Madagascar: structure, chemistry and infrared spectroscopic studies. Am Mineral 91: 1847-1856

Hawthorne FC, Henry DJ (1999) Classification of the minerals of the tourmaline group. Eur J Mineral 11: $201-215$

Henry DJ, Dutrow BL (1996) Metamorphic tourmaline and its petrologic applications. Mineral Soc America, Reviews in Mineralogy 33: 503-558

Henry DJ, Guidotti CV (1985) Tourmaline as a petrogenetic indicator mineral: an example from the staurolite-grade metapelites of NW Maine. Am Mineral 70: 1-15

Hervig RL, Moore GM, Williams LB, Peacock SM, Holloway JR, Roggensack K (2002) Isotopic and element partitioning of boron between hydrous fluid and silicate melt. Am Mineral 87: 769-774

Hughes KA, Hughes JM, Dyar MD (2001) Chemical and structural evidence for [4]B-[Si] substitution in natural tourmalines. Eur J Mineral 13: 743-747

Jiang S-Y, Palmer MR, Slack JF, Shaw DR (1999) Boron isotope systematics of tourmaline formation in the Sullivan Pb-Zn-Ag deposit, British Columbia, Canada. Chem Geol 158: 131-144

Jiang S-Y, Yang J-H, Novak M, Selway J (2003) Chemical and boron isotope compositions of tourmaline from the Lavicky leucogranite, Czech Republic. Geochem J 37: 545-556

Jung S, Mezger K, Hoernes S (2003) Petrology of basement-dominated terranes: II. Contrasting isotopic ( $\mathrm{Sr}, \mathrm{Nd}, \mathrm{Pb}$ and $\mathrm{O})$ signatures of basement-derived granites and constraints on the source region of granite (Damara orogen, Namibia). Chem Geol 99: 1-28

Kasemann S, Erzinger J, Franz G (2000) Boron recycling in the continental crust of the central Andes from the Palaeozoic to Mesozoic, NW Argentina. Contrib Mineral Petrol 140: 328-343

Keller P, Robles ER, Pérez AP, Fontan F (1999) Chemistry, paragenesis and significance of tourmaline in pegmatites of the southern tin belt, central Namibia. Chem Geol 158: 203-225

Kukla P (1992) Tectonics and sedimentation of the Late Proterozoic Damaran convergent continental margin, Khomas Hochland, Central Namibia. Geol. Surv. Namibia Mem 12: 95pp

Liu Y, Tossell JA (2005) Ab initio molecular orbital calculations for boron isotope fractionations on boric acids and borates. Geochim Cosmochim Acta 69: 3995-4006 
London D (1992) The application of experimental petrology to the genesis and crystallization of granitic pegmatites. Can Mineral 30: 499-540

London D (1999) Stability of tourmaline in peraluminous granite systems: the boron cycle from anatexis to hydrothermal aureoles. Eur J Mineral 11: 253-262

London D, Morgan GBVI, Wolf MB (1996) Boron in granitic rocks and their contact aureoles. Mineral Soc America, Rev Mineral 33: 299-330

Marschall HR, Ertl A, Hughes JM, McCammon C (2004) Metamorphic Na- and OH-rich disordered dravite with tetrahedral boron, associated with omphacie, from Syros, Greece: chemistry and structure. Eur J Mineral 16: 817-823

Marschall HR, Ludwig T, Altherr R, Kalt A, Tonarini S (2006) Syros metasomatic tourmaline: evidence for very high- $\delta^{11}$ B fluids in subduction zones. J Petrol 47: 1915-1942

Matthews A, Putlitz B, Hamiel Y, Hervig RL (2003) Volatile transport during the crystallization of anatectic melts: Oxygen, boron and hydrogen stable isotope study on the metamorphic complex of Naxos, Greece. Geochim Cosmochim Acta 67: 3145-3163

McDermott F, Harris NBW, Hawkesworth CJ (1996) Geochemical constraints on crustal anatexis: a case study from the Pan-African granitoids of Namibia. Contrib Mineral Petrol 123: 406-423

Miller RM (1983) The Pan-African Damara Orogen of South West Africa/Namibia: Geol Soc S Africa Sp Pub 11: 431-515

Morgan VI GB, London D, Kirkpatrick RJ (1990) Reconnaissance spectroscopic study of hydrous sodium aluminum borosilicate glasses. Geol Soc Am Abst Prog 22: A167

Nakano T, Nakamura E (2001) Boron isotope geochemistry of metasedimentary rocks and tourmalines in a subduction zone metamorphic suite. Phys Earth Planet Int 127: 233-252

Neuweger H (1997) Geochemische Untersuchungen an Turmaliniten in der Kuiseb-Formation, Namibia. Unpubl. Diploma-thesis, University of Giessen, Germany (in German)

Palmer MR, Swihart GH (1996) Boron isotope geochemistry: an overview. Mineral Soc America, Rev Mineral 33: 709-744

Palmer MR, London D, Morgan VI. GB, Babb HA (1992) Experimental determination of fractionation of ${ }^{11} \mathrm{~B} /{ }^{10} \mathrm{~B}$ between tourmaline and aqueous vapor. A temperature and pressure-dependent isotopic system. Chem Geol 101: 123-129

Pesquera A, Torres-Ruiz J, Gil-Crespo PP, Jiang S-Y (2005) Petrographic, chemical and B-isotopic insights into the origin of tourmaline-rich rocks and boron recycling in the Martinamor Antiform (Central Iberian Zone, Salamanca, Spain). J Petrol 46: 1013-1044

Pirajno F (1990) Geology, geochemistry and mineralization of the Erongo Volcanic Complex, Namibia. South African Journal of Geology 93: 485-504

Pirajno F, Phillips D, Armstrong RA (2000) Volcanology and eruptive histories of the Erongo volcanic complex and the Paresis igneous complex, Namibia: implications for mineral deposit styles. Communications of the Geol Surv Namibia 12: 301-312 
Pouchou JL, Pichoir F (1984) An new model of quantitative X-ray microanalysis - part 1: Application to the analysis of homogeneous samples. Recherches Aerospace 3: 13-38

Pouchou JL, Pichoir F (1985) "PAP" $(\varphi-\rho-Z)$ correction procedure for improved quantitative microanalysis. In: Armstrong JT (ed) Microbeam Analysis. San Franciso Press, San Francisco CA, pp. 104-106

Rozendaal A, Bruwer L (1995) Tourmaline nodules: indicators of hydrothermal alteration and Sn-Zn(W) mineralization in the Cape Granite Suite, South Africa. J Afr Earth Sci 21: 141-155

Samson IM, Sinclair WD (1992) Magmatic hydrothermal fluids and the origin of quartz-tourmaline orbicules in the Seagull Batholith. Yukon Territory. Can Mineral 30: 937-954

Schmidt C, Thomas R, Heinrich W (2005) Boron speciation in aqueous fluids at 22 to $600^{\circ} \mathrm{C}$ and 0.1 MPa to 2 GPa. Geochim Cosmochim Acta 69: 275-281

Schust F, Striegler R, Oelmer M (1970) Bemerkungen zur räumlichen Verteilung von TurmalinQuarz-Knollen im Eibenstocker Granitmassiv. Z Angew Geol 16: 113-122

Sinclair WD, Richardson JM (1992) Quartz-tourmaline orbicules in the Seagull Batholith, Yukon Territory. Can Mineral 30: 923-935

Slack JF, Herriman N, Barnes RG, Plimer IR (1984) Stratiform tourmalinites in metamorphic terranes and their geologic significance. Geology 12: 713-716

Smith MP, Yardley BWD (1996) The boron isotopic composition of tourmaline as a guide to fluid processes in the southwestern England orefield: an ion microprobe study. Geochim Cosmochim Acta 60: $1415-1427$

Steven NM, Moore JM (1995) Tourmalinite mineralization in the Late Proterozoic Kuiseb Formation of the Damara Orogen, central Namibia: evidence for a replacement origin. Econ Geol 90: 1098-1117

Taylor BE, Palmer MR, Slack JF (1999) Mineralizing fluids in the Kidd Creek massive sulfide deposit, Ontario: Evidence from oxygen, hydrogen, and boron isotopes in tourmaline. Econ Geol Monograph 10: 389-414

Taylor RP, Ikingura JR, Fallick AE, Huang Y, Watkinson DH (1992) Stable isotope compositions of tourmalines from granites and related hydrothermal rocks of the Karagwe-Ankolean Belt, Northwest Tanzania. Chem Geol 94: 215-227

Thomas R, Förster HJ, Heinrich W (2003) The behavior of boron in a peraluminous granite-pegmatite system and associated hydrothermal solutions: a melt and fluid inclusion study. Contrib Mineral Petrol 144: 457-472

Tonarini S, Dini A, Pezzotta F, Leeman WP (1998) Boron isotopic composition of zoned (schorlelbaite) tourmalines, Mt. Capanne Li-Cs pegmatites, Elba (Italy). Eur J Mineralogy 11: 941-952

Tonarini S, Forte C, Petrini R, Ferrara G (2003) Melt/biotite ${ }^{11} \mathrm{~B} /{ }^{10} \mathrm{~B}$ isotopic fractionation and the boron local environment in the structure of volcanic glasses. Geochim Cosmochim Acta 67: $1863-1873$ 
Trumbull RB (1993) A Petrological and Rb-Sr isotopic study of an early Archean fertile granite pegmatite system: The Sinceni Pluton in Swaziland. Precam Res 61: 89-116

Trumbull RB, Bühn B, Romer RL, Volker F (2003) The petrology of basanite-tephrite intrusions in the Erongo Complex and implications for a plume origin of Cretaceous alkaline complexes in Namibia. J Petrol 44: 93-112

Trumbull RB, Chaussidon M (1999) Chemical and boron isotopic composition of magmatic and hydrothermal tourmalines from the Sinceni granite-pegmatite system in Swaziland. Chem Geol 153: $125-137$

Trumbull RB, Emmermann R, Bühn B, Gerstenberger H, Mingram B, Schmitt AK, Volker F (2000) Insights on the genesis of the Cretaceous Damaraland igneous complexes in Namibia from a Nd- and Sr-isotopic perspective. Comm Geol Surv Namibia 12: 313-324

Trumbull RB, Harris C, Frindt S, Wigand M (2004) Oxygen and neodymium isotope evidence for source diversity in Cretaceous anorogenic granites from Namibia and implications for A-type granite genesis. Lithos 73: 21-40

Veksler IV (2004) Liquid immiscibility and its role at the magmatic-hydrothermal transition: a summary of experimental studies. Chem Geol 210: 7-31

Veksler IV, Thomas R (2002) An experimental study of B-, P- and F-rich synthetic granite pegmatite at 0.1 and $0.2 \mathrm{GPa}$. Contrib Mineral Petrol 143: 673-683

Veksler IV, Thomas R, Schmidt C (2002) Experimental evidence of three coexisting immiscible fluids in synthetic granite pegmatite. Am Mineral 87: 775-779

Wiedenbeck M, Rhede D, Lieckefett R, Witzki H (2004) Cryogenic SIMS and its applications in the earth sciences. App Surf Sci 231-232: 888-892

Wigand M, Schmitt AK, Trumbull RB, Villa IM, Emmermann R (2004) Short-lived magmatic activity in an anorogenic subvolcanic complex: ${ }^{40} \mathrm{Ar} /{ }^{39} \mathrm{Ar}$ and ion microprobe $\mathrm{U}-\mathrm{Pb}$ zircon dating of the Erongo, Damaraland Province, Namibia. J Volc Geoth Res 130: 285-305

Williams LB, Hervig RL, Holloway JR, Hutcheon I (2001) Boron isotope geochemistry during diagenesis. Part 1. Experimental determination of fractionation during illitization of smectite. Geochim Cosmochim Acta 65: 1769-1782

Wunder B, Meixner A, Romer RL, Wirth R, Heinrich W (2005) The geochemical cycle of boron: Constraints from boron isotope partitioning experiments between mica and fluid. Lithos 84 : 206-216 


\section{Figure Captions}

Figure 1. (a) Simplified geologic map of the Damara Belt showing location of the Erongo and other Early Cretaceous intrusive complexes (modified from Trumbull et al., 2004). The inset boxes (b) and (c) show sampling areas of the Erongo granite (after Wigand et al., 2004) and the Kuiseb metasediments (after Neuweger, 1997), respectively.

Figure 2. Photographs showing typical occurrences of tourmaline-quartz orbicules from the Erongo granite: (a) outcrop photograph near location ER3, note hammer in middle of photograph for scale; (b) photograph of a polished rock slab of a single orbicule.

Figure 3. Photomicrographs of tourmaline occurrences in the Erongo granite. (a) poikilitic, anhedral tourmaline with prominent growth zoning from quartz-tourmaline orbicules in sample ER3 (see Fig. 6a for microprobe profile); (b) euhedral zoned tourmaline from sample ER211 (see Fig. 6d, e for microprobe profiles); (c) secondary blue tourmaline filling microcracks in color-zoned orbicular tourmaline, from sample ER2; (d) secondary vein-filling tourmaline in quartz, sample ER201; (e) color-zoned tourmaline from sample ER210 (see Fig. 6c for microprobe profile).

Figure 4. Ternary diagrams after Henry and Guidotti (1985) showing the chemical compositions of tourmalines in terms of total $\mathrm{Al}, \mathrm{Fe}$ and $\mathrm{Mg}$ (cation proportions). Diagram (a) shows data from the Erongo granite and (b) shows data for basement tourmalines. Labelled fields are: (1) Li-rich granitoid pegmatites and aplites, (2) Li-poor granitoids, pegmatites and aplites, (3) $\mathrm{Fe}^{3+}$-rich quartz-tourmaline rocks (altered granitoids), (4) metapelites and metapsammites with A1saturating phase, (5) metapelites and metapsammites lacking Al-saturating phase, (6) $\mathrm{Fe}^{3+}$-rich quartz-tourmaline rocks, calc-silicate rocks and metapelites, (7) low-Ca metaultramafic rocks and $\mathrm{Cr}-\mathrm{V}$-rich metasediments, (8) metacarbonates and meta-pyroxenites

Figure 5. Selected variation diagrams showing the variations in chemical composition of tourmaline from the Erongo granite and basement samples, based on atoms per formula unit (see Table 1).

Figure 6. Examples of compositional zoning measured by electron microprobe across zoned tourmaline crystals from the Erongo granite. All diagrams represent half-profile proceeding from rim (left) to core (right). The positions of the profiles are shown in photomicrographs on Fig. 3. Open circles represent points analysed for boron isotope composition by SIMS and the $\delta^{11} \mathrm{~B}$ values are given.

Figure 7. Frequency histograms of boron isotope compositions of tourmaline from the Erongo granite and basement samples from in-situ SIMS analysis. Note the bimodal distribution of values in the Erongo granite with peak compositions for the main-stage (group 1) tourmalines at -10\%o \pm 2 , and the isotopically heavy samples from late-stage tourmalines (groups 2 and 3). Most basement tourmalines overlap with the Erongo group 1 tourmalines, supporting an origin of B in the Erongo granite from the local basement (see text). 
Figure 8. Sketch illustrating a possible scenario for the formation of tourmaline-quartz segregations in the Erongo granite and for the differences in B-isotopic composition between main- and latestage tourmalines. See text for discussions.

Figure 9. Rayleigh fractionation curves showing the changes in $\delta^{11} \mathrm{~B}$ values of a fluid from which tourmaline crystallizes as a function of the fraction of boron remaining (see text). The solid curve was calculated using the tourmaline-water fraction factor for $650^{\circ} \mathrm{C}$ from Palmer et al. (1992) and the dotted curve was calculated for the same temperature but using a fractionation factor for B exchange from tetrahedral to trigonal coordination (Wunder et al., 2005). Also shown are the average compositions for main-stage Erongo tourmalines (-10\%) and the heaviest late-stage tourmaline $(-1 \%)$. The isotopic shift between the two could be achieved by Rayleigh fractionation after $70-90 \%$ depletion of boron from the fluid. 

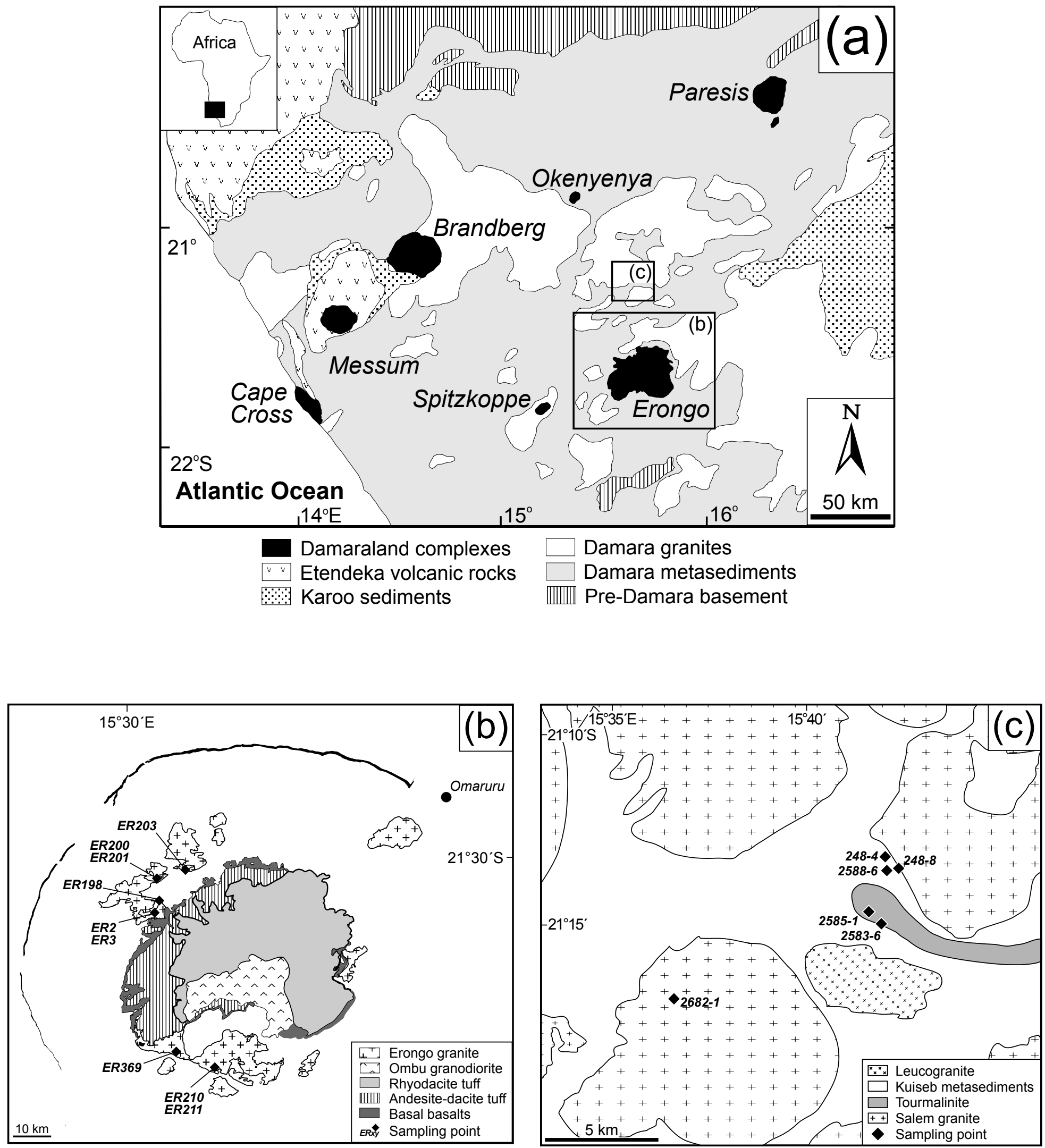

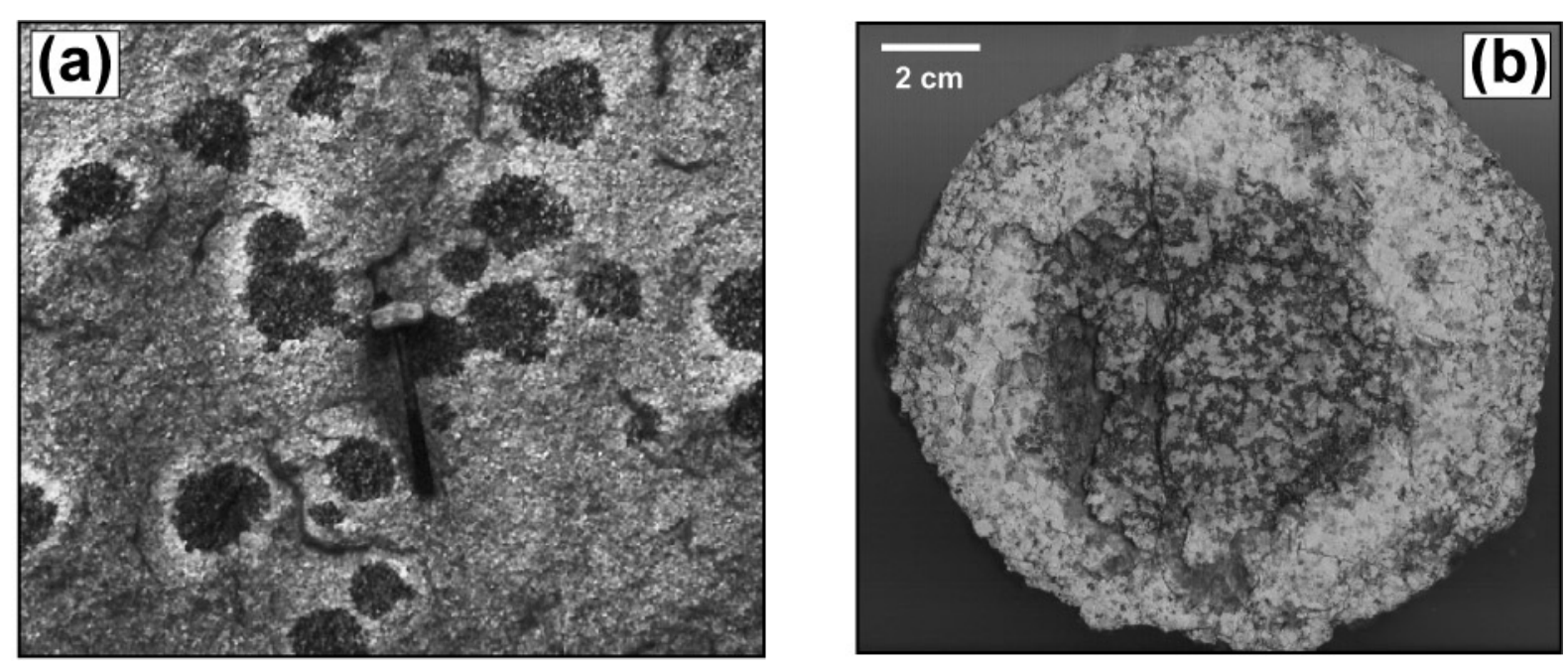

Figure 2 

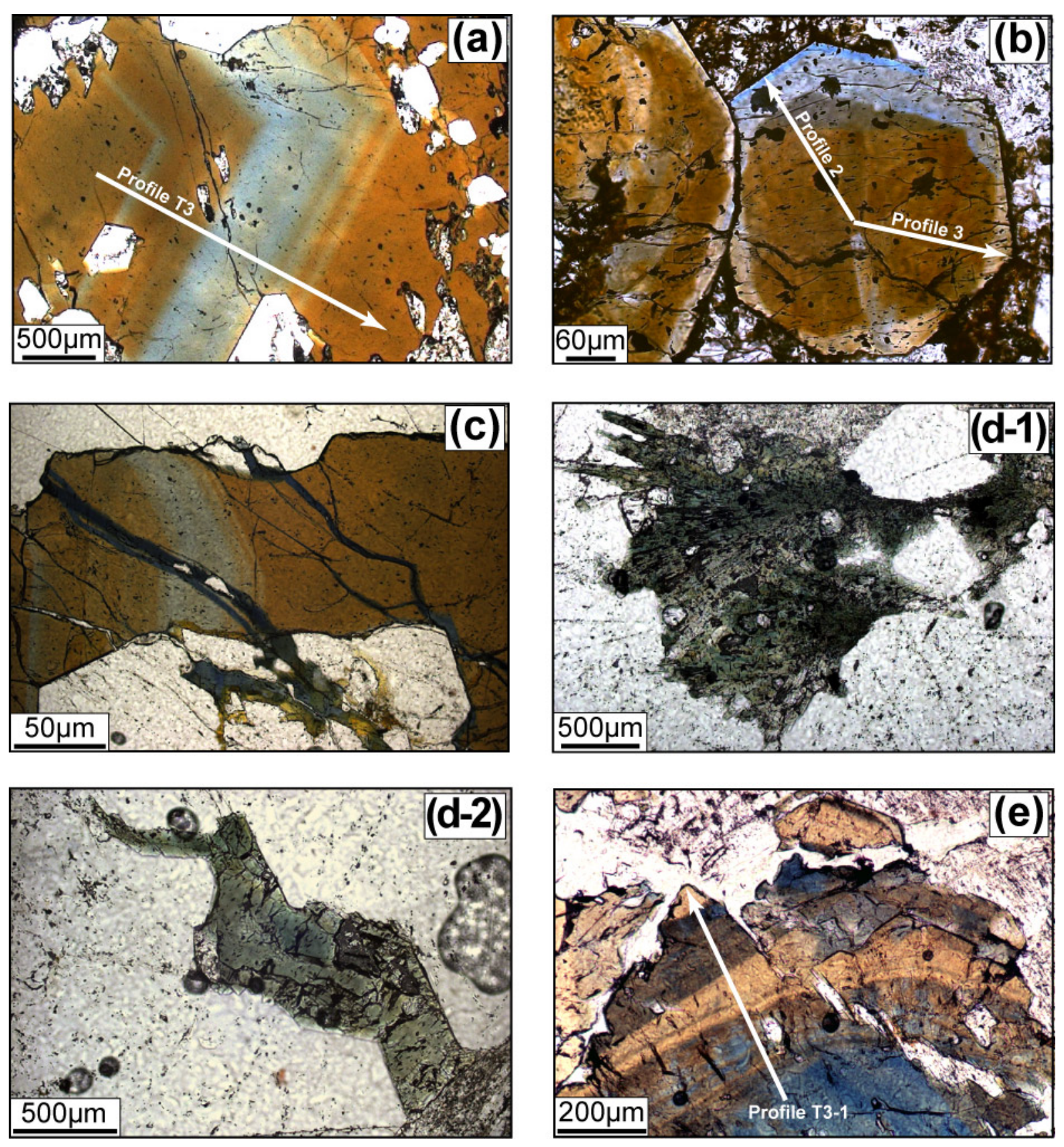


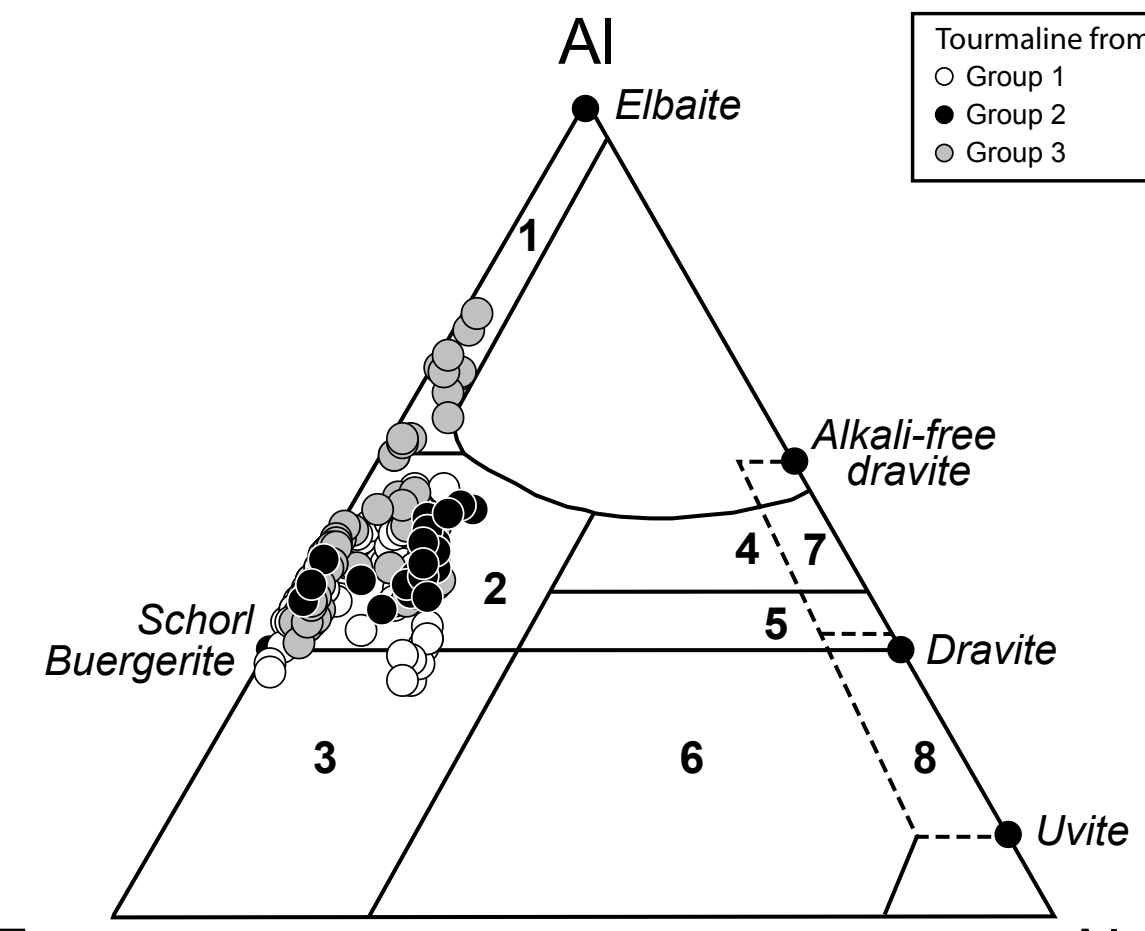

$\mathrm{Al}_{50} \mathrm{Fe}_{50}$

$\mathrm{Al}_{50} \mathrm{Mg}_{50}$

(b)

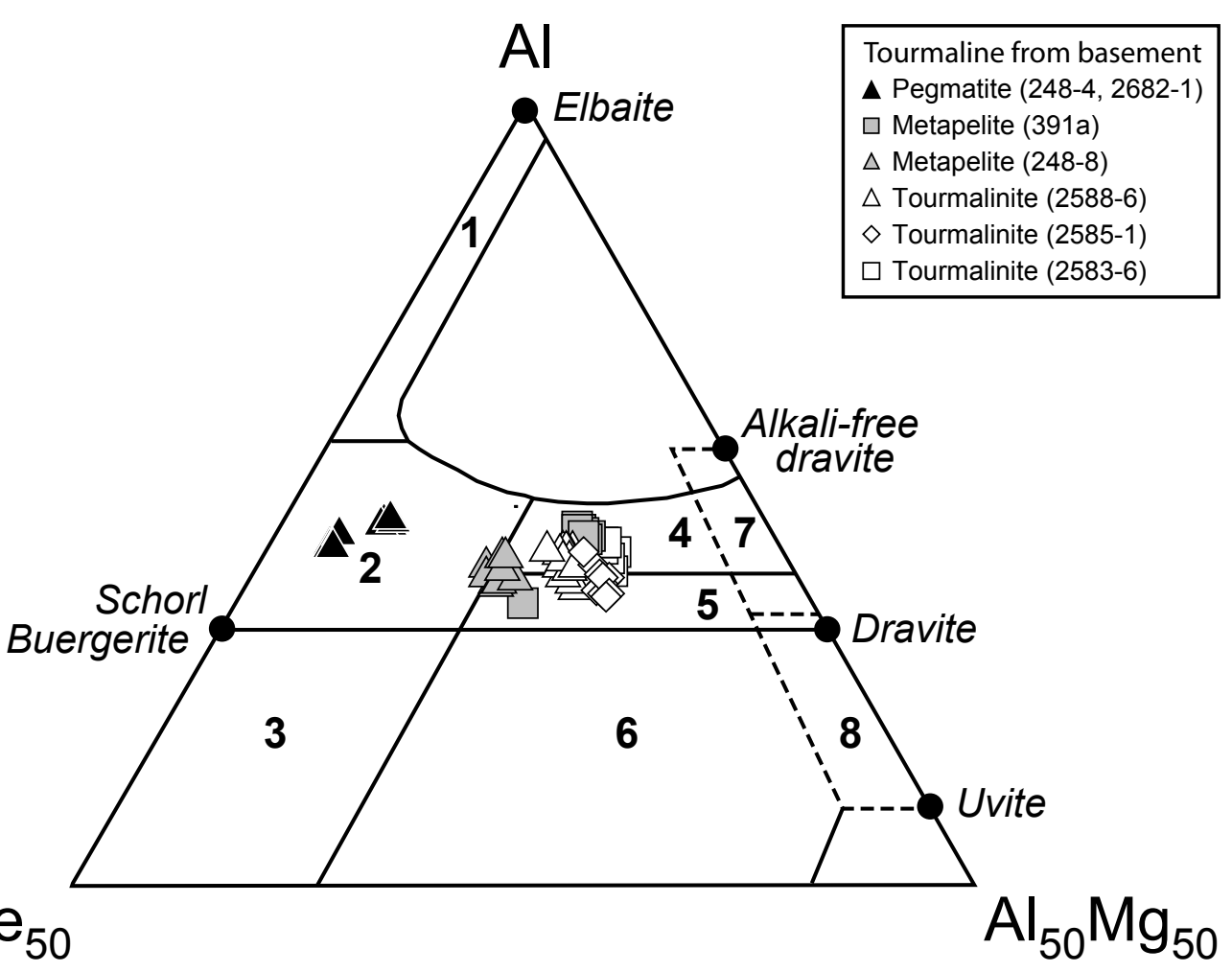

Figure 4 

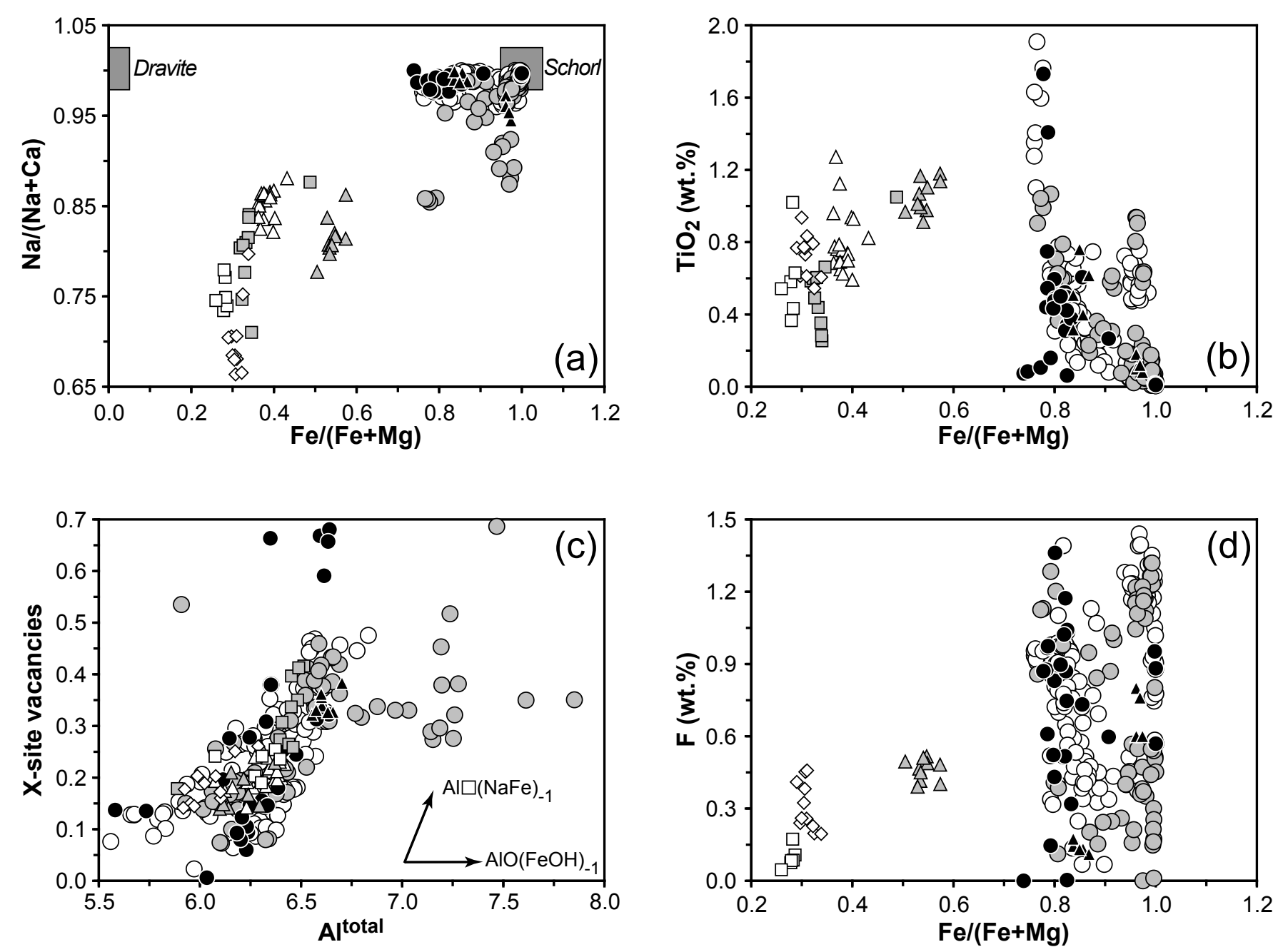
Rim ER 3 T3 $(2270 \mu m ; 20$ points $)$ Core

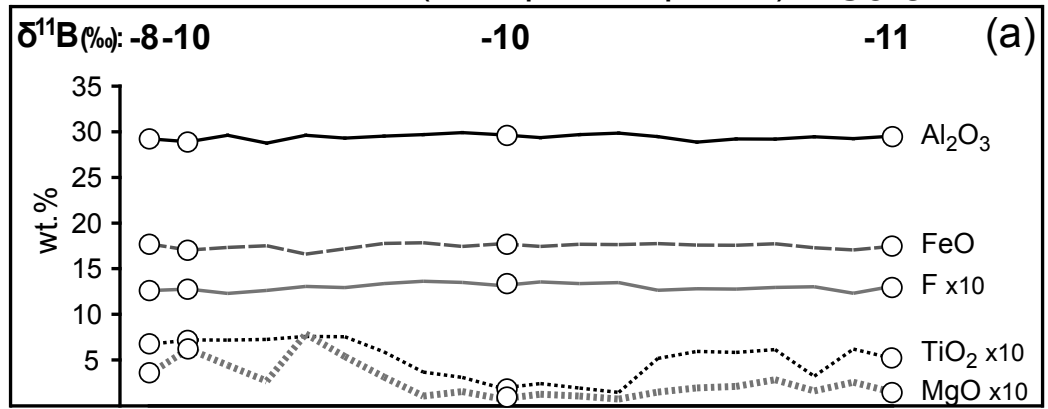

ER 210 T3-3b (310 $\mu \mathrm{m} ; 20$ points)

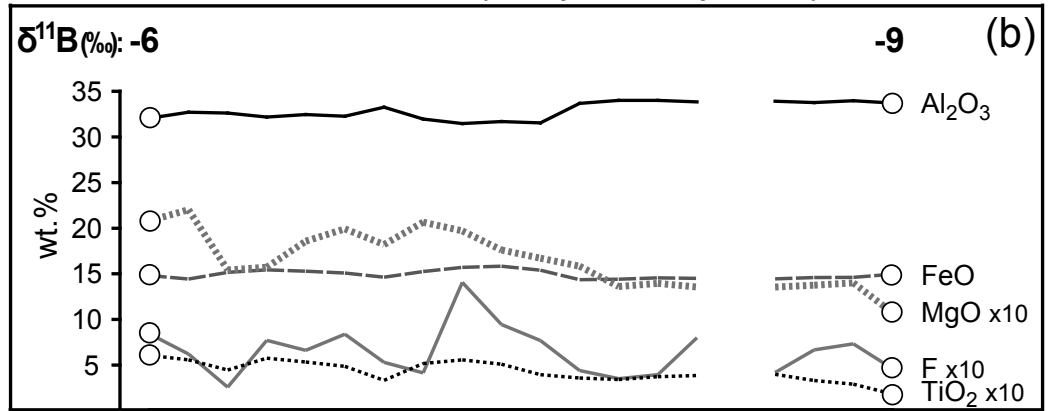

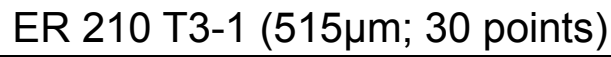

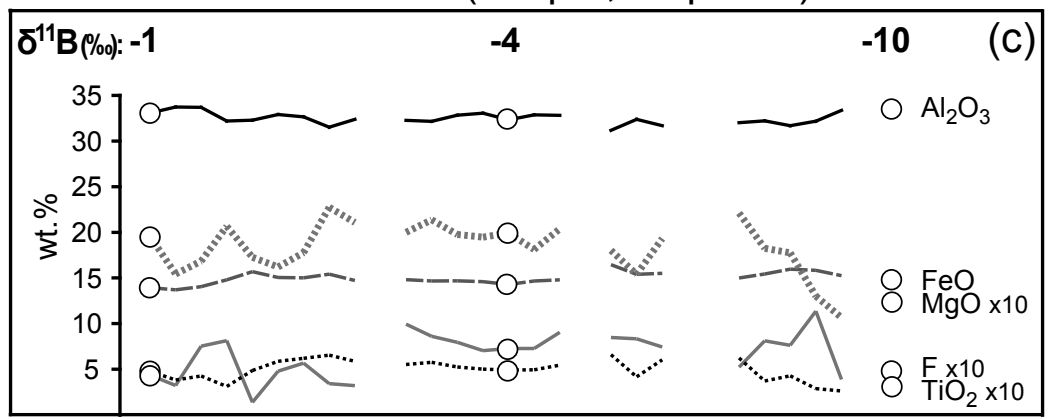

ER 211 T1-Profile $2(200 \mu \mathrm{m} ; 15$ points)

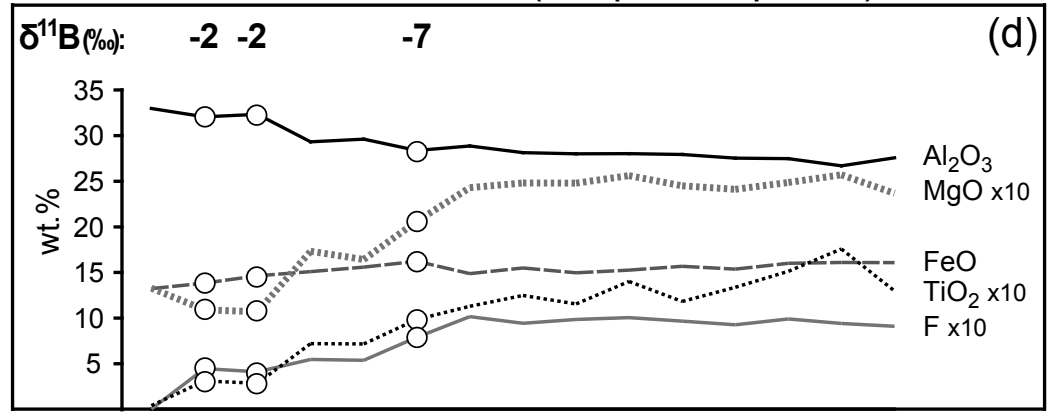

ER 211 T1-Profile $3(200 \mu \mathrm{m} ; 15$ points $)$

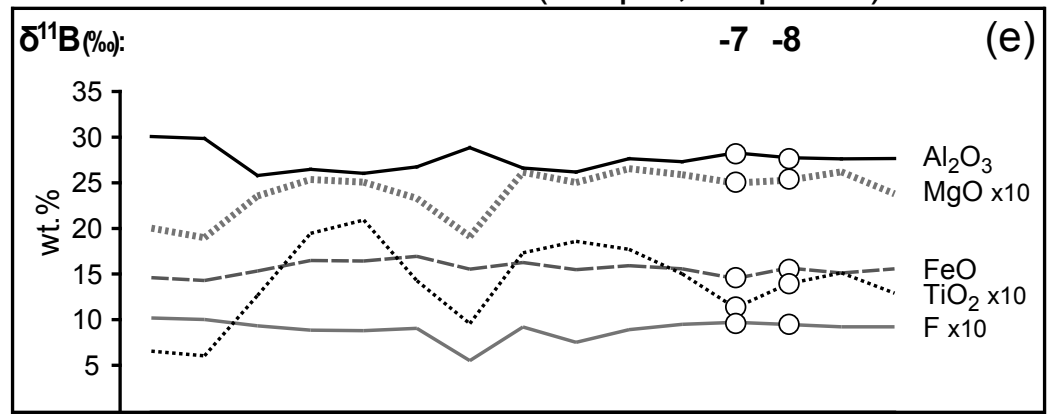



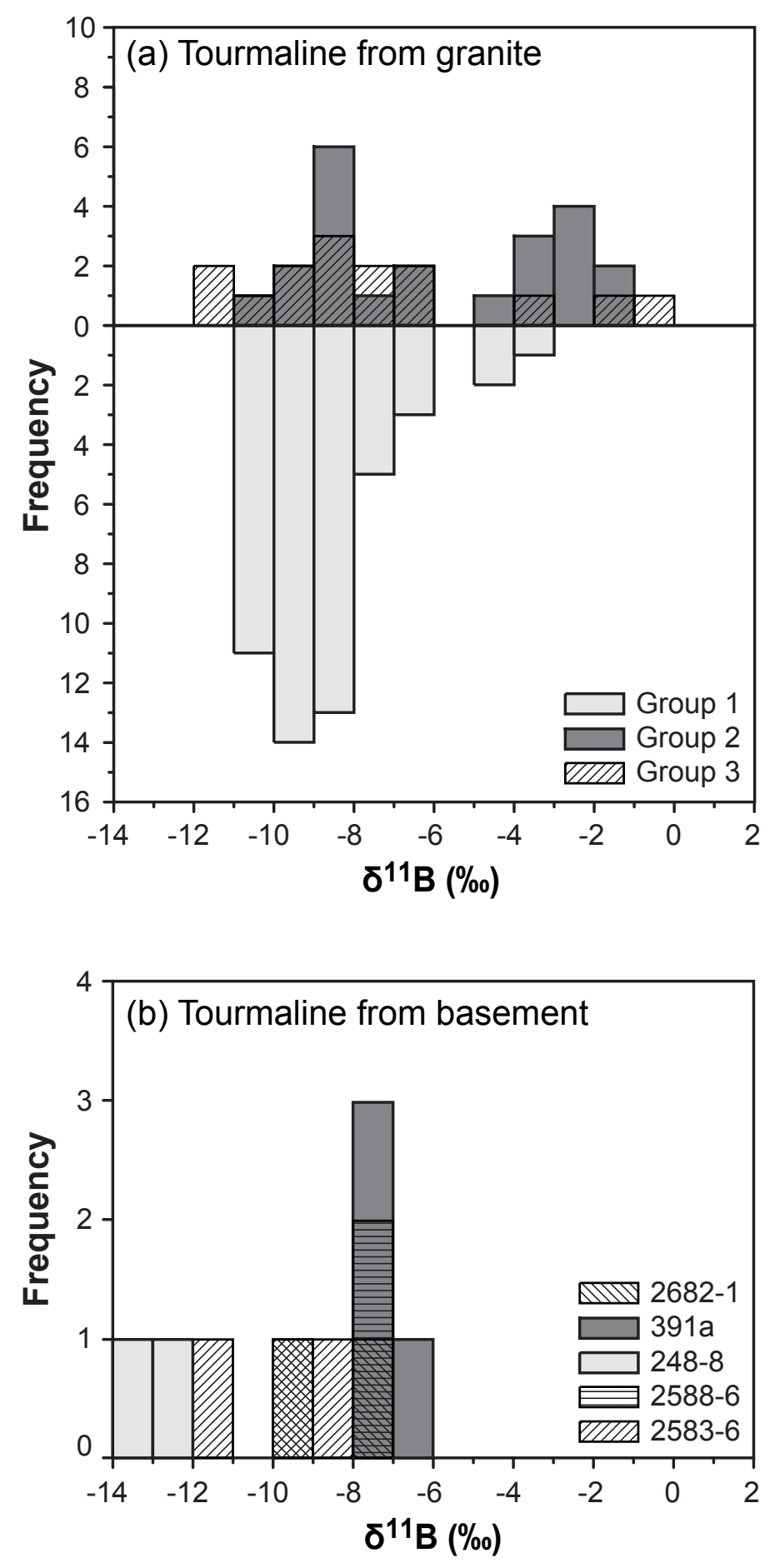

Figure 7 


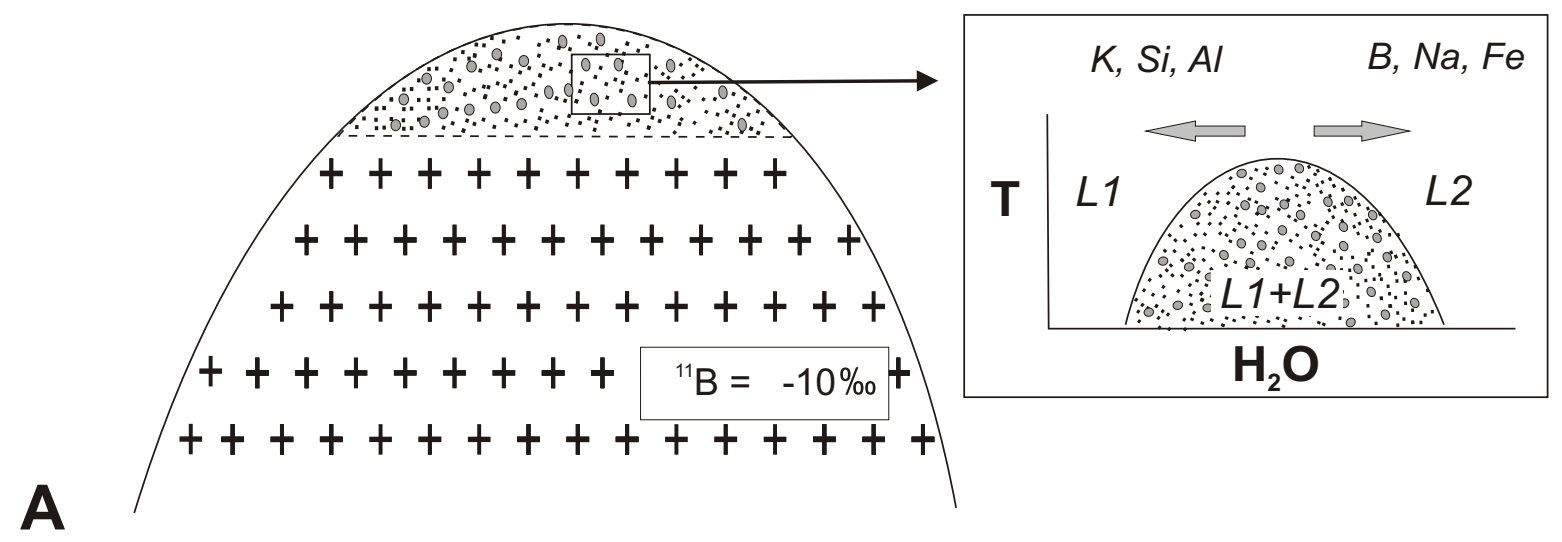

Magma Evolution: The Erongo granite forms from tourmaline-rich metapelitic source rocks and inherits their B-isotope composition. Extreme magma differentiation leads to liquid immiscibility between silicic (L1) and hydrous (L2) melts in the roof zone, with partitioning of $\mathrm{B}, \mathrm{Na}$, and Fe to L2. There is no Bisotope fractionation at this stage and boron in $\mathrm{L} 2$ retains the isotope ratio of the bulk magma $(-10 \%)$.

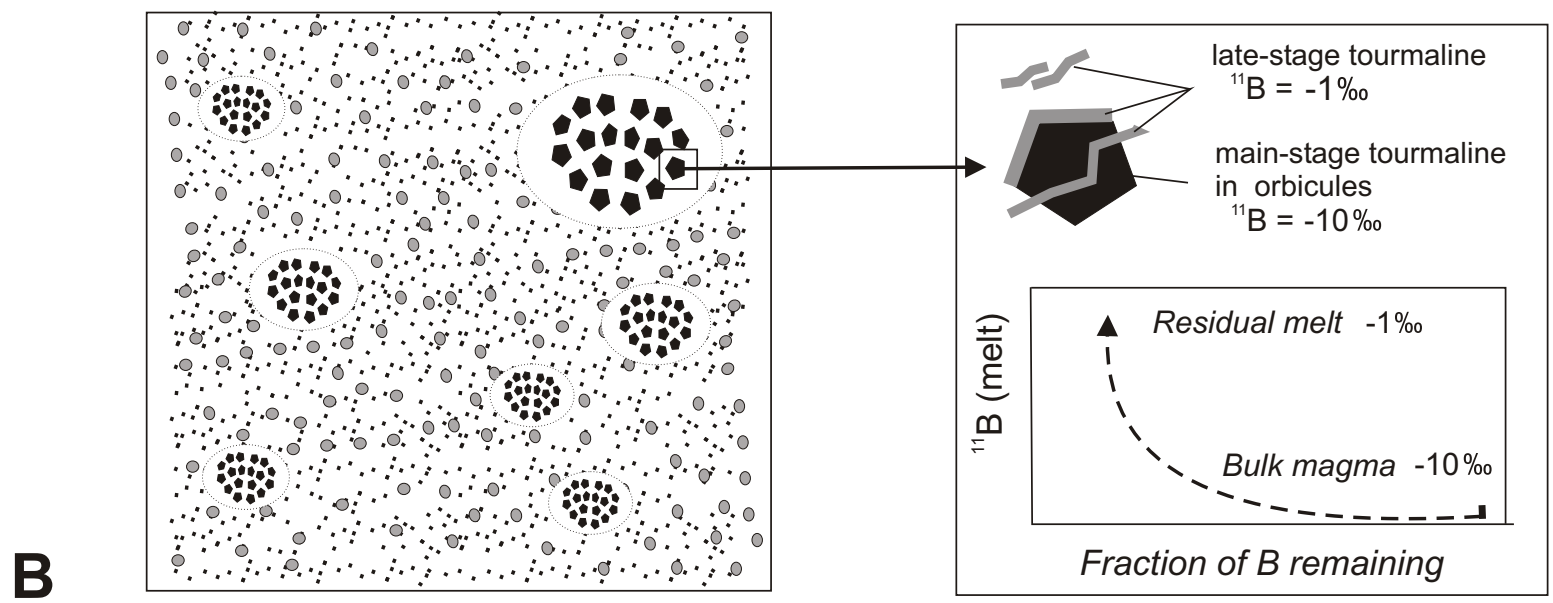

Main-stage tourmaline: forms in quartz-tourmaline orbicules after reaction of intergranular L2-melt with matrix feldspars of nearly-crystallized granite. The widespread precipitation of main-stage tourmaline strongly depletes the $\mathrm{L} 2$ melt in boron, and tourmaline-melt isotope fractionation increases ${ }^{11} \mathrm{~B} /{ }^{10} \mathrm{~B}$ ratio in the residual melt.

Late-stage tourmaline: crystallizes locally from ${ }^{11} \mathrm{~B}$-enriched, residual L2-melt and/or aqueous fluid derived from it. This late tourmaline overgrows main-stage crystals and forms microveinlets. 


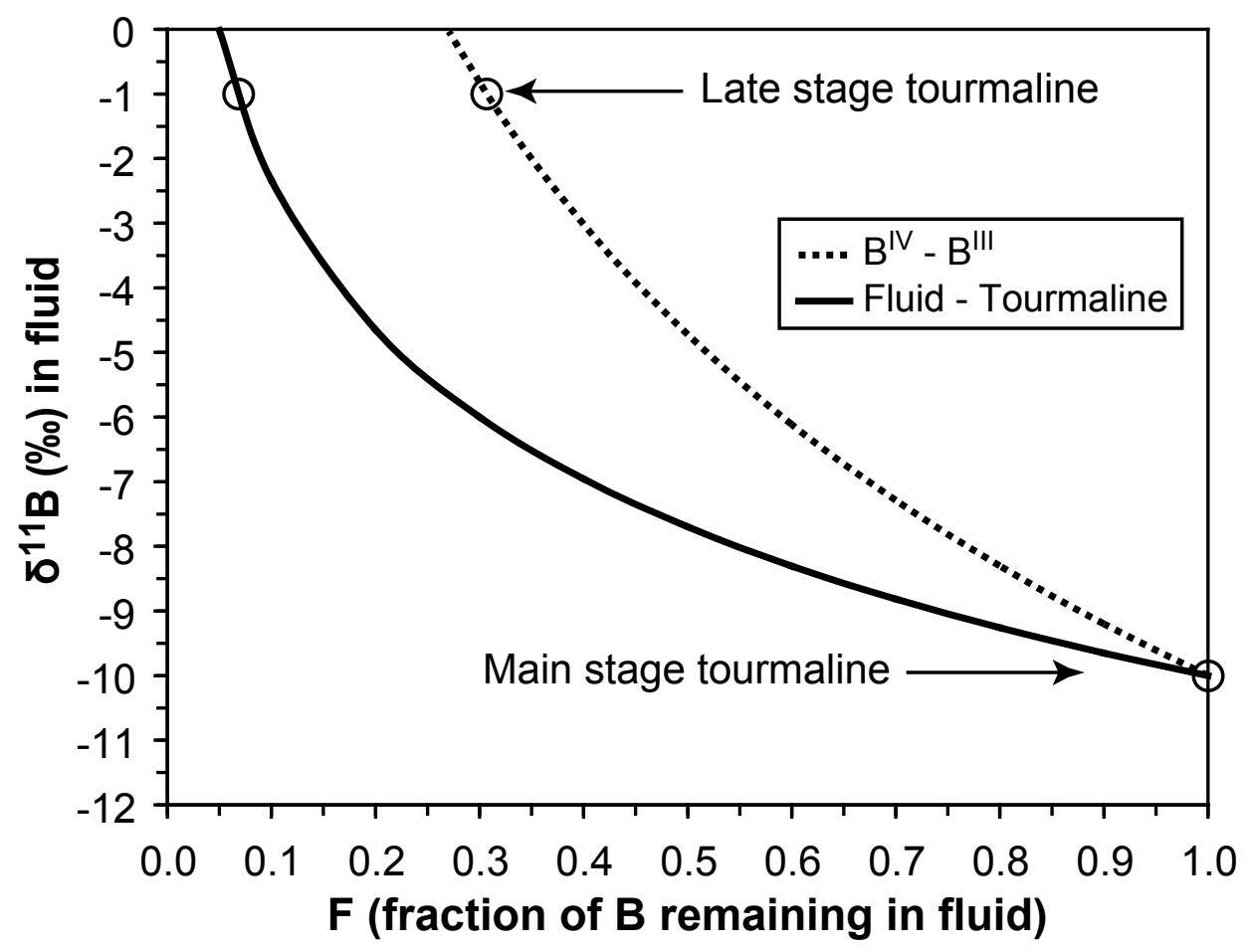

Figure 9 
Table 1. Selected chemical analyses and B isotope ratios of tourmalines from the Erongo granite and basement samples.

\begin{tabular}{|c|c|c|c|c|c|c|c|c|c|c|c|c|c|c|c|}
\hline $\begin{array}{l}\text { Sample } \\
\text { Long. ( }\left({ }^{\circ} \mathrm{E}\right)\end{array}$ & $\frac{E R 2}{15^{\circ} 33.0^{\prime}}$ & $\frac{\text { ER 3 }}{15^{\circ} 33.0^{\prime}}$ & & $\frac{\text { ER } 198}{15^{\circ} 33.0^{\prime}}$ & $\frac{\text { ER } 200}{15^{\circ} 36.7^{\prime}}$ & $\frac{\text { ER } 201}{15^{\circ} 36.7^{\prime}}$ & $\frac{E R 210}{15^{\circ} 38.1^{\prime}}$ & $\frac{\text { ER } 211}{15^{\circ} 38.1^{\prime}}$ & & & $\frac{248-8}{15^{\circ} 42.9^{\prime}}$ & $\frac{2583-6}{15^{\circ} 41.3^{\prime}}$ & $\frac{2682-1}{15^{\circ} 33.9^{\prime}}$ & $\frac{2588-6}{15^{\circ} 42.2^{\prime}}$ & $\frac{391 \mathrm{a}}{16^{\circ} 13.7^{\prime}}$ \\
\hline Lat. $\left({ }^{\circ} \mathbf{S}\right)$ & $21^{\circ} 34.6^{\prime}$ & $21^{\circ} 34.6^{\prime}$ & & $21^{\circ} 34.6^{\prime}$ & $21^{\circ} 30.7^{\prime}$ & $21^{\circ} 30.7^{\prime}$ & $21^{\circ} 50.0^{\prime}$ & $21^{\circ} 50.0^{\prime}$ & & & $21^{\circ} 13.3^{\prime}$ & $21^{\circ} 15.0^{\prime}$ & $21^{\circ} 15.8^{\prime}$ & $21^{\circ} 13.6^{\prime}$ & $22^{\circ} 42.9^{\prime}$ \\
\hline Group $^{a}$ & 1 & 1 & 1 & 1 & 3 & 3 & 2 & 1 & 2 & 2 & Metapelite & Tourmalinite & Pegmatite & Tourmalinite & Metapelite \\
\hline $\mathrm{SiO}_{2}(\mathrm{wt} . \%$ ) & 35.7 & 35.3 & 35.2 & 35.5 & 37.4 & 35.5 & 36.1 & 35.5 & 35.8 & 37.2 & 36.1 & 37.3 & 35.6 & 37.3 & 36.9 \\
\hline $\mathrm{TiO}_{2}$ & 0.01 & 0.52 & 0.68 & 0.02 & 0.13 & 0.19 & 0.48 & 1.91 & 0.75 & 0.06 & 0.91 & 0.63 & 0.62 & 0.72 & 1.05 \\
\hline $\mathrm{Al}_{2} \mathrm{O}_{3}$ & 31.2 & 29.6 & 31.8 & 30.4 & 36.6 & 33.3 & 32.9 & 27.5 & 30.5 & 32.0 & 31.0 & 32.8 & 33.1 & 33.1 & 30.1 \\
\hline MgO & 0.01 & 0.15 & 0.39 & 0.00 & 0.12 & 1.23 & 1.95 & 2.83 & 2.27 & 1.66 & 4.95 & 7.42 & 1.22 & 6.41 & 5.94 \\
\hline $\mathrm{MnO}$ & 0.12 & 0.13 & 0.11 & 0.11 & 0.01 & 0.06 & 0.12 & 0.17 & 0.14 & 0.04 & 0.36 & 0.05 & 0.20 & 0.02 & 0.04 \\
\hline $\mathrm{FeO}$ & 18.4 & 17.5 & 16.3 & 19.4 & 10.0 & 14.6 & 13.9 & 16.4 & 14.8 & 13.9 & 10.4 & 5.32 & 14.3 & 6.97 & 10.07 \\
\hline Zno & 0.01 & 0.17 & 0.04 & 0.05 & 0.01 & 0.00 & & 0.07 & 0.00 & 0.10 & & & & & \\
\hline $\mathrm{CaO}$ & 0.01 & 0.16 & 0.08 & 0.01 & 0.10 & 0.13 & 0.10 & 0.12 & 0.08 & 0.01 & 0.91 & 1.13 & 0.05 & 0.64 & 0.57 \\
\hline $\mathrm{Na}_{2} \mathrm{O}$ & 2.15 & 2.31 & 2.11 & 2.21 & 2.15 & 2.02 & 2.27 & 2.67 & 2.37 & 1.02 & 2.09 & 1.77 & 2.00 & 2.12 & 2.23 \\
\hline $\mathrm{K}_{2} \mathrm{O}$ & 0.05 & 0.07 & 0.05 & 0.07 & 0.03 & 0.04 & 0.02 & 0.07 & 0.04 & 0.01 & 0.05 & 0.01 & 0.04 & 0.04 & 0.01 \\
\hline $\mathbf{F}$ & 0.88 & 1.31 & 1.16 & 0.90 & 1.11 & 0.20 & 0.43 & 0.91 & 0.97 & 0.00 & 0.51 & 0.11 & 0.11 & & \\
\hline$F=0$ & -0.37 & -0.55 & -0.52 & -0.38 & -0.47 & -0.09 & -0.18 & -0.38 & -0.41 & 0.00 & -0.22 & -0.05 & -0.05 & & \\
\hline $\mathrm{H}_{2} \mathrm{O}$ & 2.39 & 2.24 & 2.60 & & 1.82 & & & 2.46 & 2.40 & 2.22 & & 1.69 & 2.40 & & \\
\hline $\mathrm{Li}_{2} \mathrm{O}$ & 0.03 & 0.02 & 0.02 & & 0.78 & & & 0.01 & 0.01 & 0.01 & & 0.00 & 0.01 & & \\
\hline $\mathrm{B}_{2} \mathrm{O}_{3}$ & 10.74 & 10.39 & 10.50 & & 10.31 & & & 10.66 & 10.28 & 10.24 & & 9.56 & 10.33 & & \\
\hline Sum & 101.4 & 99.2 & 100.6 & 88.2 & 100.2 & 87.1 & 88.1 & 100.9 & 100.0 & 98.5 & 87.0 & 97.8 & 100.0 & 87.3 & 86.9 \\
\hline \multicolumn{16}{|l|}{ Atoms p.f.u. } \\
\hline Si & 6.05 & 6.08 & 5.94 & 6.07 & 6.16 & 5.98 & 6.03 & 6.04 & 6.08 & 6.40 & 6.04 & 6.33 & 6.08 & 6.07 & 6.11 \\
\hline $\mathrm{Al}(\mathrm{T})$ & 0.00 & 0.00 & 0.06 & 0.00 & 0.00 & 0.02 & 0.00 & 0.00 & 0.00 & 0.00 & 0.00 & 0.00 & 0.00 & 0.00 & 0.00 \\
\hline $\mathrm{Al}(\mathrm{Z})$ & 6.00 & 6.00 & 6.00 & 6.00 & 6.00 & 6.00 & 6.00 & 5.52 & 6.00 & 6.00 & 6.00 & 6.00 & 6.00 & 6.00 & 5.89 \\
\hline $\mathrm{Al}(\mathrm{Y})$ & 0.24 & 0.01 & 0.26 & 0.13 & 1.10 & 0.61 & 0.48 & 0.00 & 0.10 & 0.49 & 0.11 & 0.56 & 0.66 & 0.34 & 0.00 \\
\hline $\mathrm{Ti}$ & 0.00 & 0.07 & 0.09 & 0.00 & 0.02 & 0.02 & 0.06 & 0.24 & 0.10 & 0.01 & 0.11 & 0.08 & 0.08 & 0.09 & 0.13 \\
\hline $\mathbf{M g}$ & 0.00 & 0.04 & 0.10 & 0.00 & 0.03 & 0.31 & 0.48 & 0.72 & 0.57 & 0.43 & 1.23 & 1.87 & 0.31 & 1.55 & 1.47 \\
\hline $\mathrm{Mn}$ & 0.02 & 0.02 & 0.02 & 0.02 & 0.00 & 0.01 & 0.02 & 0.02 & 0.02 & 0.01 & 0.05 & 0.01 & 0.03 & 0.00 & 0.01 \\
\hline $\mathrm{Fe}$ & 2.62 & 2.52 & 2.30 & 2.78 & 1.38 & 2.05 & 1.93 & 2.34 & 2.10 & 2.00 & 1.45 & 0.75 & 2.04 & 0.95 & 1.40 \\
\hline $\mathrm{Zn}$ & 0.00 & 0.02 & 0.01 & 0.01 & 0.00 & 0.00 & 0.00 & 0.01 & 0.00 & 0.01 & 0.00 & 0.00 & 0.00 & 0.00 & 0.00 \\
\hline $\mathrm{Ca}$ & 0.00 & 0.03 & 0.02 & 0.00 & 0.02 & 0.02 & 0.02 & 0.02 & 0.01 & 0.00 & 0.16 & 0.20 & 0.01 & 0.11 & 0.10 \\
\hline $\mathrm{Na}$ & 0.71 & 0.77 & 0.69 & 0.73 & 0.69 & 0.66 & 0.73 & 0.88 & 0.78 & 0.34 & 0.68 & 0.58 & 0.66 & 0.67 & 0.72 \\
\hline $\mathbf{K}$ & 0.01 & 0.02 & 0.01 & 0.02 & 0.01 & 0.01 & 0.00 & 0.02 & 0.01 & 0.00 & 0.01 & 0.00 & 0.01 & 0.01 & 0.00 \\
\hline B & 3.14 & 3.10 & 3.06 & & 2.93 & & & 3.13 & 3.01 & 3.04 & & 2.80 & 3.04 & & \\
\hline $\mathrm{Li}$ & 0.02 & 0.02 & 0.01 & & 0.51 & & & 0.01 & 0.01 & 0.00 & & 0.00 & 0.01 & & \\
\hline H & 2.70 & 2.57 & 2.93 & & 2.00 & & & 2.80 & 2.72 & 2.55 & & 1.91 & 2.73 & & \\
\hline vacancies & 0.28 & 0.18 & 0.29 & 0.25 & 0.29 & 0.31 & 0.24 & 0.08 & 0.20 & 0.66 & 0.15 & 0.21 & 0.32 & 0.21 & 0.18 \\
\hline${ }^{11} \mathrm{~B} /{ }^{10} \mathrm{~B}$ & 4.005 & 4.000 & 4.003 & 4.009 & 3.999 & 4.040 & 4.038 & 4.011 & 4.024 & 4.034 & 3.989 & 4.003 & 4.006 & 4.011 & 4.016 \\
\hline $1 \sigma(\%)$ & 0.60 & 0.55 & 0.54 & 0.48 & 0.64 & 0.60 & 0.41 & 0.67 & 0.53 & 0.56 & 0.57 & 0.87 & 0.95 & 0.61 & 0.66 \\
\hline ठ'B & -9.6 & -10.8 & -10.1 & -8.5 & -11.1 & -0.9 & -1.3 & -8.0 & -4.9 & -2.3 & -13.4 & -10.0 & -9.3 & -8.0 & -6.7 \\
\hline
\end{tabular}

Analyses by electron microprobe (total $\mathrm{Fe}$ as $\mathrm{FeO}$ ) and by $\mathrm{SIMS}\left(\mathrm{H}_{2} \mathrm{O}, \mathrm{Li}_{2} \mathrm{O}, \mathrm{B}_{2} \mathrm{O}_{3}\right.$ and B-isotopes)

${ }^{a}$ Tourmaline groups (in Erongo granite): 1- main-stage orbicular tourmaline, 2- veinlets and overgrowths in or on group 1 grains, 3- interstitial grains in granite matrix

${ }^{b}$ calculations based on 15 cations in T, Z and Y sites (Henry and Dutrow, 1996), or based on 31 total anions for samples with B, H and Li data 
Table 2 Example of boron isotope analyses by SIMS on reference tourmalines

\begin{tabular}{|c|c|c|c|c|}
\hline Analysis Date & ${ }^{11} \mathrm{~B} /{ }^{10} \mathrm{~B}$ & $1 \sigma(\%))^{a}$ & $\mathrm{IMF}^{\mathrm{b}}$ & $\delta^{11} \mathrm{~B}(\% \circ)^{\mathrm{c}}$ \\
\hline \multicolumn{5}{|c|}{ Dravite $\left({ }^{11} \mathrm{~B} /{ }^{10} \mathrm{~B}=4.017\right.$ and $\left.\delta^{11} \mathrm{~B}=-6.6\right)$} \\
\hline 24-01-05 & 3.834 & 0.73 & 0.9544 & -5.4 \\
\hline 24-01-05 & 3.831 & 0.67 & 0.9537 & -6.2 \\
\hline 24-01-05 & 3.827 & 0.62 & 0.9527 & -7.2 \\
\hline 24-01-05 & 3.821 & 0.87 & 0.9512 & -8.8 \\
\hline 24-01-05 & 3.833 & 0.51 & 0.9542 & -5.7 \\
\hline Mean & 3.829 & & & -6.6 \\
\hline External precision in permil ${ }^{d}$ & 1.4 & & & \\
\hline \multicolumn{5}{|c|}{ Elbaite $\left({ }^{11} \mathrm{~B} /{ }^{10} \mathrm{~B}=4.001\right.$ and $\left.\delta^{11} \mathrm{~B}=-10.4\right)$} \\
\hline 24-01-05 & 3.813 & 0.55 & 0.9530 & -10.8 \\
\hline 24-01-05 & 3.807 & 0.73 & 0.9515 & -12.4 \\
\hline 24-01-05 & 3.802 & 0.67 & 0.9503 & -13.7 \\
\hline 24-01-05 & 3.809 & 0.58 & 0.9520 & -11.9 \\
\hline 24-01-05 & 3.812 & 0.72 & 0.9528 & -11.1 \\
\hline Mean & 3.809 & & & -12.0 \\
\hline External precision in permil ${ }^{d}$ & 1.2 & & & \\
\hline \multicolumn{5}{|c|}{ Schorl $\left({ }^{11} \mathrm{~B} /{ }^{10} \mathrm{~B}=3.993\right.$ and $\left.\delta^{11} \mathrm{~B}=-12.5\right)$} \\
\hline $24-01-05$ & 3.810 & 0.56 & 0.9542 & -11.6 \\
\hline 24-01-05 & 3.814 & 0.54 & 0.9552 & -10.6 \\
\hline 24-01-05 & 3.813 & 0.51 & 0.9549 & -10.8 \\
\hline 24-01-05 & 3.816 & 0.60 & 0.9557 & -10.1 \\
\hline Mean & 3.813 & & & -10.8 \\
\hline External precision in permil ${ }^{d}$ & 0.7 & & & \\
\hline \multicolumn{5}{|c|}{$\begin{array}{l}\text { The data represent multiple analyses of } 3 \text { tourmaline standards collected on one day. } \\
\text { a) Internal precision in permil for single analysis from } 50 \text { cycles (standard deviation / mean)*1000 } \\
\text { b) Instrumental mass fractionation }\left({ }^{11} \mathrm{~B} /{ }^{10} \mathrm{~B} \text { measured } /{ }^{11} \mathrm{~B} /{ }^{10} \mathrm{~B} \text { standard) }\right.\end{array}$} \\
\hline
\end{tabular}


Appendix A. Chemical analyses and B isotope ratios of tourmalines from the Erongo granite.

\begin{tabular}{|c|c|c|c|c|c|c|c|c|c|c|c|c|c|c|}
\hline $\begin{array}{l}\text { Sample } \\
\text { Long. }\left({ }^{\circ} \mathrm{E}\right) \\
\text { Lat. }\left({ }^{\circ} \mathrm{S}\right)\end{array}$ & $\begin{array}{l}\text { ER 2 } \\
15^{\circ} 33.0^{\prime} \\
21^{\circ} 34.6^{\prime}\end{array}$ & & & & & & & & & & & & & \\
\hline Group $^{a}$ & 1 & 1 & 1 & 1 & 1 & 1 & 2 & 2 & 2 & 2 & 2 & 2 & 2 & 2 \\
\hline $\mathrm{SiO}_{2}(\mathrm{wt} . \%)$ & 34.9 & 36.0 & 34.9 & 35.7 & 34.5 & 34.8 & 35.0 & 34.8 & 34.8 & 34.9 & 34.6 & 34.9 & 34.6 & 34.6 \\
\hline $\mathrm{TiO}_{2}$ & 0.26 & 0.02 & 0.46 & 0.01 & 0.65 & 0.34 & 0.46 & 0.15 & 0.49 & 0.04 & 0.12 & 0.13 & 0.70 & 0.02 \\
\hline $\mathrm{Al}_{2} \mathrm{O}_{3}$ & 30.6 & 31.6 & 30.1 & 31.2 & 30.7 & 31.4 & 29.0 & 30.2 & 30.6 & 29.5 & 28.8 & 29.9 & 30.7 & 29.5 \\
\hline $\mathrm{MgO}$ & 0.15 & 0.00 & 0.25 & 0.01 & 0.43 & 0.10 & 0.26 & 0.23 & 0.32 & 0.02 & 0.12 & 0.25 & 0.54 & 0.02 \\
\hline $\mathrm{MnO}$ & 0.18 & 0.09 & 0.14 & 0.12 & 0.09 & 0.16 & 0.13 & 0.08 & 0.14 & 0.11 & 0.13 & 0.13 & 0.09 & 0.12 \\
\hline $\mathrm{FeO}$ & 18.0 & 17.4 & 18.2 & 18.4 & 17.8 & 17.7 & 19.0 & 18.1 & 17.6 & 18.9 & 19.8 & 18.9 & 17.6 & 19.2 \\
\hline ZnO & & 0.13 & & 0.01 & & & & & & & & & & \\
\hline $\mathrm{CaO}$ & 0.14 & 0.02 & 0.16 & 0.01 & 0.12 & 0.10 & 0.02 & 0.04 & 0.09 & 0.04 & 0.02 & 0.02 & 0.17 & 0.03 \\
\hline $\mathrm{Na}_{2} \mathrm{O}$ & 2.42 & 1.84 & 2.44 & 2.15 & 2.44 & 2.34 & 2.49 & 2.40 & 2.34 & 2.57 & 2.65 & 2.48 & 2.46 & 2.35 \\
\hline $\mathrm{K}_{2} \mathrm{O}$ & 0.04 & 0.04 & 0.07 & 0.05 & 0.05 & 0.06 & 0.06 & 0.06 & 0.05 & 0.05 & 0.08 & 0.05 & 0.05 & 0.06 \\
\hline $\mathrm{F}$ & 1.37 & 0.57 & 1.23 & 0.88 & 1.25 & 1.32 & 1.10 & 0.91 & 1.06 & 1.30 & 1.17 & 0.90 & 1.33 & 0.73 \\
\hline$F=0$ & -0.58 & -0.24 & -0.52 & -0.37 & -0.53 & -0.56 & -0.46 & -0.38 & -0.45 & -0.55 & -0.49 & -0.38 & -0.56 & -0.31 \\
\hline $\mathrm{H}_{2} \mathrm{O}$ & & & & 2.39 & 2.26 & 2.33 & 2.28 & & 2.16 & & & & & \\
\hline $\mathrm{Li}_{2} \mathrm{O}$ & & & & 0.03 & 0.04 & 0.03 & 0.04 & & 0.03 & & & & & \\
\hline $\mathrm{B}_{2} \mathrm{O}_{3}$ & & & & 10.74 & 10.70 & 10.63 & 10.72 & & 10.63 & & & & & \\
\hline Sum & 87.4 & 87.5 & 87.4 & 101.4 & 100.5 & 100.8 & 100.1 & 86.7 & 99.9 & 87.4 & 87.6 & 87.6 & 88.2 & 86.5 \\
\hline \multicolumn{15}{|l|}{ Atoms p.f.u. } \\
\hline $\mathrm{Si}$ & 6.04 & 6.13 & 6.06 & 6.05 & 5.89 & 5.90 & 6.04 & 6.07 & 5.98 & 6.11 & 6.07 & 6.05 & 5.98 & 6.06 \\
\hline $\mathrm{Al}(\mathrm{T})$ & 0.00 & 0.00 & 0.00 & 0.00 & 0.11 & 0.10 & 0.00 & 0.00 & 0.02 & 0.00 & 0.00 & 0.00 & 0.02 & 0.00 \\
\hline $\mathrm{Al}(\mathrm{Z})$ & 6.00 & 6.00 & 6.00 & 6.00 & 6.00 & 6.00 & 5.90 & 6.00 & 6.00 & 6.00 & 5.95 & 6.00 & 6.00 & 6.00 \\
\hline $\mathrm{Al}(\mathrm{Y})$ & 0.25 & 0.35 & 0.16 & 0.24 & 0.06 & 0.19 & 0.00 & 0.20 & 0.19 & 0.09 & 0.00 & 0.11 & 0.22 & 0.10 \\
\hline $\mathrm{Ti}$ & 0.03 & 0.00 & 0.06 & 0.00 & 0.08 & 0.04 & 0.06 & 0.02 & 0.06 & 0.00 & 0.02 & 0.02 & 0.09 & 0.00 \\
\hline Mg & 0.04 & 0.00 & 0.07 & 0.00 & 0.11 & 0.03 & 0.07 & 0.06 & 0.08 & 0.00 & 0.03 & 0.07 & 0.14 & 0.01 \\
\hline Mn & 0.03 & 0.01 & 0.02 & 0.02 & 0.01 & 0.02 & 0.02 & 0.01 & 0.02 & 0.02 & 0.02 & 0.02 & 0.01 & 0.02 \\
\hline $\mathrm{Fe}$ & 2.61 & 2.49 & 2.64 & 2.62 & 2.55 & 2.51 & 2.74 & 2.64 & 2.54 & 2.78 & 2.91 & 2.74 & 2.54 & 2.81 \\
\hline $\mathrm{Zn}$ & 0.00 & 0.02 & 0.00 & 0.00 & 0.00 & 0.00 & 0.00 & 0.00 & 0.00 & 0.00 & 0.00 & 0.00 & 0.00 & 0.00 \\
\hline $\mathrm{Ca}$ & 0.03 & 0.00 & 0.03 & 0.00 & 0.02 & 0.02 & 0.00 & 0.01 & 0.02 & 0.01 & 0.00 & 0.00 & 0.03 & 0.01 \\
\hline $\mathrm{Na}$ & 0.81 & 0.61 & 0.82 & 0.71 & 0.81 & 0.77 & 0.83 & 0.81 & 0.78 & 0.87 & 0.90 & 0.83 & 0.82 & 0.80 \\
\hline K & 0.01 & 0.01 & 0.02 & 0.01 & 0.01 & 0.01 & 0.01 & 0.01 & 0.01 & 0.01 & 0.02 & 0.01 & 0.01 & 0.01 \\
\hline B & & & & 3.14 & 3.15 & 3.11 & 3.19 & & 3.15 & & & & & \\
\hline $\mathrm{Li}$ & & & & 0.02 & 0.03 & 0.02 & 0.03 & & 0.02 & & & & & \\
\hline H & & & & 2.70 & 2.57 & 2.64 & 2.63 & & 2.48 & & & & & \\
\hline vacancies & 0.15 & 0.38 & 0.13 & 0.28 & 0.16 & 0.20 & 0.15 & 0.17 & 0.19 & 0.11 & 0.08 & 0.15 & 0.13 & 0.18 \\
\hline $11 \mathrm{~B} /{ }^{10} \mathrm{~B}$ & 4.001 & 4.003 & 4.002 & 4.005 & 4.007 & 4.004 & 4.009 & 4.009 & 4.007 & 4.010 & 4.011 & 4.006 & 3.999 & 4.008 \\
\hline $1 \sigma(\%)$ & 0.60 & 0.64 & 0.50 & 0.60 & 0.70 & 0.60 & 0.54 & 0.59 & 0.55 & 0.43 & 0.43 & 0.42 & 0.35 & 0.34 \\
\hline$\delta^{11} \mathrm{~B}$ & -10.6 & -10.1 & -10.4 & -9.6 & -9.1 & -9.8 & -8.5 & -8.5 & -9.1 & -8.3 & -8.1 & -9.4 & -10.9 & -8.9 \\
\hline
\end{tabular}


Appendix A. Chemical analyses and B isotope ratios of tourmalines from the Erongo granite.

\begin{tabular}{|c|c|c|c|c|c|c|c|c|c|c|c|c|c|}
\hline $\begin{array}{l}\text { Sample } \\
\text { Long. }\left({ }^{\circ} \mathrm{E}\right) \\
\text { Lat. }\left({ }^{\circ} \mathrm{S}\right)\end{array}$ & $\begin{array}{l}\text { ER 3 } \\
15^{\circ} 33.0^{\prime} \\
21^{\circ} 34.6^{\prime}\end{array}$ & & & & & & & & & & & & \\
\hline Group $^{a}$ & 1 & 1 & 1 & 1 & 1 & 1 & 1 & 1 & 1 & 1 & 1 & 1 & 1 \\
\hline $\mathrm{TiO}_{2}$ & 0.62 & 0.15 & 0.68 & 0.72 & 0.02 & 0.03 & 0.01 & 0.47 & 0.49 & 0.65 & 0.72 & 0.52 & 0.68 \\
\hline $\mathrm{Al}_{2} \mathrm{O}_{3}$ & 30.3 & 29.9 & 31.6 & 28.9 & 30.4 & 30.5 & 29.4 & 32.2 & 32.1 & 31.3 & 29.7 & 29.6 & 31.8 \\
\hline $\mathrm{MgO}$ & 0.25 & 0.08 & 0.50 & 0.63 & 0.02 & 0.00 & 0.00 & 0.44 & 0.45 & 0.47 & 0.45 & 0.15 & 0.39 \\
\hline $\mathrm{ZnO}$ & & 0.05 & 0.11 & 0.06 & 0.00 & 0.07 & 0.12 & 0.06 & 0.07 & 0.01 & 0.10 & 0.17 & 0.04 \\
\hline $\mathrm{CaO}$ & 0.17 & 0.14 & 0.15 & 0.17 & 0.02 & 0.01 & 0.04 & 0.08 & 0.08 & 0.16 & 0.14 & 0.16 & 0.08 \\
\hline $\mathrm{Na}_{2} \mathrm{O}$ & 2.49 & 2.21 & 2.19 & 2.23 & 2.15 & 2.08 & 2.30 & 2.03 & 2.00 & 2.20 & 2.29 & 2.31 & 2.11 \\
\hline $\mathrm{K}_{2} \mathrm{O}$ & 0.06 & 0.05 & 0.03 & 0.07 & 0.04 & 0.05 & 0.06 & 0.05 & 0.03 & 0.05 & 0.05 & 0.07 & 0.05 \\
\hline $\mathbf{F}$ & 1.33 & 1.35 & 1.23 & 1.28 & 1.05 & 0.78 & 1.02 & 1.23 & 1.17 & 1.22 & 1.23 & 1.31 & 1.16 \\
\hline$F=0$ & -0.56 & -0.57 & -0.52 & -0.54 & -0.44 & -0.33 & -0.43 & -0.52 & -0.49 & -0.51 & -0.52 & -0.55 & \\
\hline $\mathrm{H}_{2} \mathrm{O}$ & & & & & & & & & & 2.34 & 2.44 & 2.24 & 2.60 \\
\hline \multicolumn{14}{|l|}{ Atoms p.f.u. } \\
\hline $\mathrm{Si}$ & 6.06 & 6.20 & 6.00 & 6.20 & 6.11 & 6.05 & 6.10 & 6.04 & 6.06 & 5.94 & 6.05 & 6.08 & 5.94 \\
\hline $\mathrm{Al}(\mathrm{T})$ & 0.00 & 0.00 & 0.00 & 0.00 & 0.00 & 0.00 & 0.00 & 0.00 & 0.00 & 0.06 & 0.00 & 0.00 & 0.06 \\
\hline $\operatorname{Al}(Z)$ & 6.00 & 6.00 & 6.00 & 6.00 & 6.00 & 6.00 & 6.00 & 6.00 & 6.00 & 6.00 & 5.95 & 6.00 & 6.00 \\
\hline $\mathrm{Al}(\mathrm{Y})$ & 0.17 & 0.16 & 0.35 & 0.00 & 0.20 & 0.18 & 0.01 & 0.45 & 0.46 & 0.21 & 0.00 & 0.01 & 0.26 \\
\hline $\mathrm{Ti}$ & 0.08 & 0.02 & 0.09 & 0.10 & 0.00 & 0.00 & 0.00 & 0.06 & 0.06 & 0.08 & 0.09 & 0.07 & 0.09 \\
\hline $\mathbf{M g}$ & 0.06 & 0.02 & 0.13 & 0.16 & 0.01 & 0.00 & 0.00 & 0.11 & 0.11 & 0.12 & 0.11 & 0.04 & 0.10 \\
\hline$M n$ & 0.02 & 0.02 & 0.01 & 0.01 & 0.01 & 0.02 & 0.01 & 0.02 & 0.01 & 0.01 & 0.02 & 0.02 & 0.02 \\
\hline $\mathrm{Fe}$ & 2.61 & 2.58 & 2.41 & 2.51 & 2.66 & 2.74 & 2.85 & 2.31 & 2.28 & 2.42 & 2.47 & 2.52 & 2.30 \\
\hline $\mathrm{Zn}$ & 0.00 & 0.01 & 0.01 & 0.01 & 0.00 & 0.01 & 0.02 & 0.01 & 0.01 & 0.00 & 0.01 & 0.02 & 0.01 \\
\hline $\mathrm{Ca}$ & 0.03 & 0.03 & 0.03 & 0.03 & 0.00 & 0.00 & 0.01 & 0.01 & 0.02 & 0.03 & 0.03 & 0.03 & 0.02 \\
\hline $\mathrm{Na}$ & 0.84 & 0.75 & 0.72 & 0.76 & 0.72 & 0.69 & 0.77 & 0.67 & 0.66 & 0.72 & 0.76 & 0.77 & 0.69 \\
\hline K & 0.01 & 0.01 & 0.01 & 0.02 & 0.01 & 0.01 & 0.01 & 0.01 & 0.01 & 0.01 & 0.01 & 0.02 & 0.01 \\
\hline
\end{tabular}

Analyses by electron microprobe (total $\mathrm{Fe}$ as $\mathrm{FeO}$ ) and by SIMS $\left(\mathrm{H}_{2} \mathrm{O}, \mathrm{Li}_{2} \mathrm{O}, \mathrm{B}_{2} \mathrm{O}_{3}\right.$ and $\mathrm{B}$-isotopes)

${ }^{a}$ Tourmaline groups: 1- main-stage orbicular tourmaline, 2- veinlets and overgrowths in or on group 1 grains, 3- interstitial grains in granite matrix

${ }^{\mathrm{b}}$ calculations based on 15 cations in T, Z and Y sites (Henry and Dutrow, 1996), or based on 31 total anions for samples with B, H and Li data 
Appendix A. Chemical analyses and B isotope ratios of tourmalines from the Erongo granite.

\begin{tabular}{|c|c|c|c|c|c|c|c|c|c|c|c|c|c|c|c|c|c|c|}
\hline \multirow{2}{*}{$\begin{array}{l}\text { Sample } \\
\left.\text { Long. ( }{ }^{\circ} \mathrm{E}\right) \\
\left.\text { Lat. ( }{ }^{\circ} \mathrm{S}\right) \\
\text { Group }^{\mathrm{a}} \\
\end{array}$} & \multicolumn{8}{|c|}{$\begin{array}{l}\text { ER } 198 \\
15^{\circ} 33.0^{\prime} \\
21^{\circ} 34.6^{\prime}\end{array}$} & \multicolumn{3}{|c|}{$\begin{array}{l}\text { ER } 200 \\
15^{\circ} 36.7^{\prime} \\
21^{\circ} 30.7^{\prime}\end{array}$} & \multicolumn{7}{|l|}{$\begin{array}{l}\text { ER } 201 \\
15^{\circ} 36.7^{\prime} \\
21^{\circ} 30.7^{\prime}\end{array}$} \\
\hline & & 1 & 1 & 1 & 1 & 1 & 1 & 1 & 3 & 3 & 3 & 3 & 3 & 3 & 3 & 3 & 3 & 3 \\
\hline $\mathrm{SiO}_{2}(w t . \%)$ & 35.5 & 35.0 & 35.4 & 35.5 & 35.1 & 35.1 & 35.1 & 35.8 & 33.3 & 34.4 & 37.4 & 34.8 & 35.3 & 34.8 & 34.9 & 35.7 & 35.4 & 35.5 \\
\hline $\mathrm{TiO}_{2}$ & 0.01 & 0.02 & 0.63 & 0.02 & 0.75 & 0.53 & 0.03 & 0.01 & 0.23 & 0.03 & 0.13 & 0.08 & 0.02 & 0.08 & 0.29 & 0.20 & 0.17 & 0.19 \\
\hline $\mathrm{Al}_{2} \mathrm{O}_{3}$ & 31.1 & 30.1 & 30.5 & 30.4 & 29.9 & 29.6 & 30.1 & 31.7 & 36.3 & 36.2 & 36.6 & 32.1 & 30.8 & 29.9 & 34.6 & 33.7 & 33.5 & 33.3 \\
\hline $\mathrm{MgO}$ & 0.00 & 0.03 & 0.31 & 0.00 & 0.36 & 0.38 & 0.03 & 0.02 & 0.22 & 0.15 & 0.12 & 0.69 & 0.48 & 0.40 & 1.00 & 0.54 & 0.79 & 1.23 \\
\hline MnO & 0.10 & 0.16 & 0.10 & 0.11 & 0.16 & 0.19 & 0.14 & 0.12 & 0.06 & 0.06 & 0.01 & 0.06 & 0.08 & 0.12 & 0.03 & 0.08 & 0.08 & 0.06 \\
\hline $\mathrm{FeO}$ & 18.5 & 19.5 & 18.0 & 19.4 & 19.0 & 19.0 & 19.4 & 18.0 & 14.0 & 13.9 & 10.0 & 16.9 & 18.8 & 19.4 & 13.8 & 15.2 & 14.3 & 14.6 \\
\hline $\mathrm{ZnO}$ & 0.05 & 0.00 & 0.06 & 0.05 & 0.09 & 0.00 & 0.03 & 0.02 & 0.03 & 0.00 & 0.01 & 0.04 & 0.10 & 0.00 & 0.02 & 0.04 & & 0.00 \\
\hline $\mathrm{CaO}$ & 0.01 & 0.00 & 0.06 & 0.01 & 0.07 & 0.06 & 0.04 & 0.02 & 0.44 & 0.32 & 0.10 & 0.34 & 0.12 & 0.15 & 0.21 & 0.10 & 0.05 & 0.13 \\
\hline $\mathrm{Na}_{2} \mathrm{O}$ & 2.14 & 2.46 & 2.45 & 2.21 & 2.53 & 2.50 & 2.46 & 1.93 & 1.81 & 1.49 & 2.15 & 1.88 & 2.13 & 2.11 & 1.89 & 1.88 & 2.11 & 2.02 \\
\hline $\mathrm{K}_{2} \mathrm{O}$ & 0.05 & 0.06 & 0.05 & 0.07 & 0.07 & 0.06 & 0.06 & 0.04 & 0.01 & 0.02 & 0.03 & 0.03 & 0.04 & 0.06 & 0.04 & 0.04 & 0.04 & 0.04 \\
\hline$F$ & 0.78 & 1.24 & 1.40 & 0.90 & 1.44 & 1.39 & 1.27 & 0.58 & 0.38 & 0.35 & 1.11 & 0.26 & 0.21 & 0.55 & 0.15 & 0.40 & 0.18 & 0.20 \\
\hline$F=0$ & -0.33 & -0.52 & -0.59 & -0.38 & -0.61 & -0.59 & -0.54 & -0.25 & -0.16 & -0.15 & -0.47 & -0.11 & -0.09 & -0.23 & -0.06 & -0.17 & -0.08 & -0.09 \\
\hline $\mathrm{H}_{2} \mathrm{O}$ & & & & & & & & & 2.23 & 2.18 & 1.82 & & & & 2.71 & 2.68 & & \\
\hline $\mathrm{Li}_{2} \mathrm{O}$ & & & & & & & & & 0.11 & 0.05 & 0.78 & & & & 0.03 & 0.03 & & \\
\hline $\mathrm{B}_{2} \mathrm{O}_{3}$ & & & & & & & & & 11.47 & 11.48 & 10.31 & & & & 10.03 & 10.07 & & \\
\hline Sum & 87.9 & 88.1 & 88.4 & 88.2 & 88.9 & 88.2 & 88.1 & 88.0 & 100.4 & 100.6 & 100.2 & 87.1 & 88.0 & 87.4 & 99.7 & 100.4 & 86.6 & 87.1 \\
\hline \multicolumn{19}{|l|}{ Atoms p.f.u. } \\
\hline Si & 6.08 & 6.04 & 6.07 & 6.07 & 6.01 & 6.05 & 6.05 & 6.08 & 5.61 & 5.77 & 6.16 & 5.94 & 6.01 & 6.00 & 5.94 & 6.04 & 6.02 & 5.98 \\
\hline $\mathrm{Al}(\mathrm{T})$ & 0.00 & 0.00 & 0.00 & 0.00 & 0.00 & 0.00 & 0.00 & 0.00 & 0.39 & 0.23 & 0.00 & 0.06 & 0.00 & 0.00 & 0.06 & 0.00 & 0.00 & 0.02 \\
\hline $\mathrm{Al}(\mathrm{Z})$ & 6.00 & 6.00 & 6.00 & 6.00 & 6.00 & 6.00 & 6.00 & 6.00 & 6.00 & 6.00 & 6.00 & 6.00 & 6.00 & 6.00 & 6.00 & 6.00 & 6.00 & 6.00 \\
\hline $\mathrm{Al}(\mathrm{Y})$ & 0.26 & 0.13 & 0.17 & 0.13 & 0.03 & 0.03 & 0.12 & 0.35 & 0.81 & 0.93 & 1.10 & 0.38 & 0.17 & 0.08 & 0.89 & 0.73 & 0.71 & 0.61 \\
\hline $\mathrm{Ti}$ & 0.00 & 0.00 & 0.08 & 0.00 & 0.10 & 0.07 & 0.00 & 0.00 & 0.03 & 0.00 & 0.02 & 0.01 & 0.00 & 0.01 & 0.04 & 0.03 & 0.02 & 0.02 \\
\hline Mg & 0.00 & 0.01 & 0.08 & 0.00 & 0.09 & 0.10 & 0.01 & 0.00 & 0.05 & 0.04 & 0.03 & 0.18 & 0.12 & 0.10 & 0.25 & 0.14 & 0.20 & 0.31 \\
\hline$M n$ & 0.02 & 0.02 & 0.01 & 0.02 & 0.02 & 0.03 & 0.02 & 0.02 & 0.01 & 0.01 & 0.00 & 0.01 & 0.01 & 0.02 & 0.00 & 0.01 & 0.01 & 0.01 \\
\hline $\mathrm{Fe}$ & 2.64 & 2.81 & 2.57 & 2.78 & 2.73 & 2.73 & 2.79 & 2.55 & 1.98 & 1.95 & 1.38 & 2.42 & 2.68 & 2.79 & 1.96 & 2.15 & 2.04 & 2.05 \\
\hline $\mathrm{Zn}$ & 0.01 & 0.00 & 0.01 & 0.01 & 0.01 & 0.00 & 0.00 & 0.00 & 0.00 & 0.00 & 0.00 & 0.01 & 0.01 & 0.00 & 0.00 & 0.01 & 0.00 & 0.00 \\
\hline $\mathrm{Ca}$ & 0.00 & 0.00 & 0.01 & 0.00 & 0.01 & 0.01 & 0.01 & 0.00 & 0.08 & 0.06 & 0.02 & 0.06 & 0.02 & 0.03 & 0.04 & 0.02 & 0.01 & 0.02 \\
\hline $\mathrm{Na}$ & 0.71 & 0.82 & 0.81 & 0.73 & 0.84 & 0.83 & 0.82 & 0.63 & 0.59 & 0.48 & 0.69 & 0.62 & 0.70 & 0.70 & 0.62 & 0.62 & 0.69 & 0.66 \\
\hline K & 0.01 & 0.01 & 0.01 & 0.02 & 0.01 & 0.01 & 0.01 & 0.01 & 0.00 & 0.00 & 0.01 & 0.01 & 0.01 & 0.01 & 0.01 & 0.01 & 0.01 & 0.01 \\
\hline B & & & & & & & & & 3.34 & 3.32 & 2.93 & & & & 2.95 & 2.94 & & \\
\hline $\mathrm{Li}$ & & & & & & & & & 0.07 & 0.03 & 0.51 & & & & 0.02 & 0.02 & & \\
\hline H & & & & & & & & & 2.51 & 2.44 & 2.00 & & & & 3.08 & 3.03 & & \\
\hline vacancies & 0.28 & 0.16 & 0.17 & 0.25 & 0.13 & 0.14 & 0.16 & 0.35 & 0.33 & 0.46 & 0.29 & 0.31 & 0.27 & 0.26 & 0.33 & 0.36 & 0.29 & 0.31 \\
\hline $11 \mathrm{~B} /{ }^{10} \mathrm{~B}$ & 4.013 & 4.010 & 4.008 & 4.009 & 4.004 & 4.002 & 4.008 & 4.007 & 4.003 & 4.006 & 3.999 & 4.013 & 4.036 & 4.031 & 4.015 & 4.010 & 4.019 & 4.040 \\
\hline $1 \sigma(\%)$ & 0.44 & 0.55 & 0.62 & 0.48 & 0.63 & 0.51 & 0.59 & 0.53 & 0.70 & 0.87 & 0.64 & 0.64 & 0.83 & 0.72 & 0.58 & 0.68 & 0.67 & 0.60 \\
\hline$\delta^{11} \mathrm{~B}$ & -7.7 & -8.2 & -8.7 & -8.5 & -9.7 & -10.3 & -8.7 & -9.0 & -10.1 & -9.3 & -11.1 & -7.6 & -1.9 & -3.2 & -7.1 & -8.4 & -6.0 & -0.9 \\
\hline
\end{tabular}

${ }^{a}$ Tourmaline groups: 1- main-stage orbicular tourmaline, 2- veinlets and overgrowths in or on group 1 grains, 3- interstitial grains in granite matrix

${ }^{b}$ calculations based on 15 cations in T, Z and Y sites (Henry and Dutrow, 1996), or based on 31 total anions for samples with B, H and Li data 
Appendix A. Chemical analyses and B isotope ratios of tourmalines from the Erongo granite.

\begin{tabular}{|c|c|c|c|c|c|c|c|c|c|c|c|c|c|c|c|c|c|c|c|c|}
\hline $\begin{array}{l}\text { Sample } \\
\text { Long. }\left({ }^{\circ} \mathrm{E}\right) \\
\text { Lat. }\left({ }^{\circ} \mathrm{S}\right)\end{array}$ & $\begin{array}{l}\text { ER 210 } \\
15^{\circ} 38.1^{\prime} \\
21^{\circ} 50.0^{\prime}\end{array}$ & & & & & & & & & & & & & & & & & & & \\
\hline Group $^{a}$ & 1 & 1 & 1 & 1 & 1 & 1 & 1 & 1 & 1 & 1 & 2 & 2 & 2 & 2 & 2 & 3 & 3 & 3 & 3 & 3 \\
\hline $\mathrm{SiO}_{2}$ (wt.\%) & 35.4 & 35.6 & 35.6 & 35.8 & 36.0 & 35.8 & 35.4 & 36.1 & 35.5 & 36.4 & 36.1 & 35.9 & 35.9 & 36.4 & 36.2 & 35.4 & 34.5 & 34.4 & 36.0 & 36.0 \\
\hline $\mathrm{TiO}_{2}$ & 0.41 & 0.41 & 0.59 & 0.17 & 0.30 & 0.46 & 0.75 & 0.17 & 0.49 & 0.31 & 0.48 & 0.60 & 0.34 & 0.52 & 0.49 & 0.23 & 1.07 & 0.99 & 0.57 & 0.71 \\
\hline $\mathrm{Al}_{2} \mathrm{O}_{3}$ & 32.7 & 32.6 & 31.7 & 33.5 & 33.7 & 31.7 & 29.6 & 33.5 & 32.2 & 33.4 & 32.9 & 31.8 & 31.3 & 31.5 & 31.5 & 32.0 & 32.1 & 31.8 & 32.3 & 31.0 \\
\hline MgO & 1.67 & 1.71 & 1.88 & 1.61 & 1.37 & 1.96 & 1.40 & 1.06 & 1.98 & 1.23 & 1.95 & 2.06 & 1.84 & 1.86 & 1.95 & 1.35 & 2.10 & 2.33 & 2.01 & 2.09 \\
\hline $\mathrm{MnO}$ & 0.07 & 0.10 & 0.10 & 0.12 & 0.08 & 0.09 & 0.11 & 0.05 & 0.08 & 0.12 & 0.12 & 0.11 & 0.08 & 0.12 & 0.10 & 0.14 & 0.12 & 0.10 & 0.14 & 0.14 \\
\hline $\mathrm{FeO}$ & 14.7 & 14.8 & 15.2 & 14.8 & 14.3 & 15.2 & 17.5 & 14.8 & 14.2 & 14.7 & 13.9 & 14.7 & 15.4 & 15.2 & 15.7 & 15.8 & 14.3 & 14.5 & 14.2 & 15.1 \\
\hline $\mathrm{ZnO}$ & 0.04 & 0.07 & 0.00 & 0.01 & & & & & & & & & & & & 0.01 & 0.07 & 0.03 & & \\
\hline $\mathrm{CaO}$ & 0.08 & 0.10 & 0.09 & 0.11 & 0.02 & 0.07 & 0.07 & 0.02 & 0.11 & 0.01 & 0.10 & 0.07 & 0.05 & 0.03 & 0.06 & 0.05 & 0.63 & 0.65 & 0.08 & 0.10 \\
\hline $\mathrm{Na}_{2} \mathrm{O}$ & 2.15 & 2.14 & 2.20 & 2.11 & 2.11 & 2.74 & 2.88 & 2.10 & 2.44 & 2.11 & 2.27 & 2.52 & 2.81 & 2.71 & 2.79 & 2.15 & 2.13 & 2.10 & 2.49 & 2.68 \\
\hline $\mathrm{K}_{2} \mathrm{O}$ & 0.04 & 0.04 & 0.05 & 0.03 & 0.02 & 0.04 & 0.04 & 0.04 & 0.06 & 0.05 & 0.02 & 0.05 & 0.04 & 0.04 & 0.04 & 0.04 & 0.07 & 0.06 & 0.04 & 0.03 \\
\hline $\mathrm{F}$ & 0.95 & 0.96 & 0.87 & 0.59 & 0.07 & 0.78 & 0.77 & 0.45 & 0.72 & 0.48 & 0.43 & 0.83 & 1.04 & 0.52 & 1.02 & 0.95 & 1.28 & 1.13 & 0.41 & 1.20 \\
\hline$F=0$ & -0.40 & -0.40 & -0.37 & -0.25 & -0.03 & -0.33 & -0.32 & -0.19 & -0.30 & -0.20 & -0.18 & -0.35 & -0.44 & -0.22 & -0.43 & -0.40 & -0.54 & -0.48 & -0.17 & -0.51 \\
\hline \multicolumn{21}{|l|}{$\mathrm{H}_{2} \mathrm{O}$} \\
\hline \multicolumn{21}{|l|}{$\mathrm{Li}_{2} \mathrm{O}$} \\
\hline \multicolumn{21}{|l|}{$\mathrm{B}_{2} \mathrm{O}_{3}$} \\
\hline Sum & 87.8 & 88.1 & 87.9 & 88.5 & 88.0 & 88.5 & 88.3 & 88.1 & 87.5 & 88.6 & 88.1 & 88.3 & 88.3 & 88.6 & 89.5 & 87.6 & 87.8 & 87.7 & 88.1 & 88.6 \\
\hline \multicolumn{21}{|l|}{ Atoms p.f.u. ${ }^{b}$} \\
\hline Si & 5.96 & 5.97 & 6.00 & 5.95 & 6.00 & 6.03 & 6.06 & 6.03 & 6.00 & 6.05 & 6.03 & 6.03 & 6.07 & 6.10 & 6.04 & 5.99 & 5.85 & 5.84 & 6.04 & 6.07 \\
\hline $\mathrm{Al}(\mathrm{T})$ & 0.04 & 0.03 & 0.00 & 0.05 & 0.00 & 0.00 & 0.00 & 0.00 & 0.00 & 0.00 & 0.00 & 0.00 & 0.00 & 0.00 & 0.00 & 0.01 & 0.15 & 0.16 & 0.00 & 0.00 \\
\hline $\operatorname{Al}(Z)$ & 6.00 & 6.00 & 6.00 & 6.00 & 6.00 & 6.00 & 5.97 & 6.00 & 6.00 & 6.00 & 6.00 & 6.00 & 6.00 & 6.00 & 6.00 & 6.00 & 6.00 & 6.00 & 6.00 & 6.00 \\
\hline $\mathrm{Al}(\mathrm{Y})$ & 0.44 & 0.42 & 0.30 & 0.50 & 0.62 & 0.28 & 0.00 & 0.60 & 0.41 & 0.54 & 0.48 & 0.31 & 0.23 & 0.23 & 0.20 & 0.37 & 0.28 & 0.21 & 0.38 & 0.16 \\
\hline $\mathrm{Ti}$ & 0.05 & 0.05 & 0.07 & 0.02 & 0.04 & 0.06 & 0.10 & 0.02 & 0.06 & 0.04 & 0.06 & 0.08 & 0.04 & 0.07 & 0.06 & 0.03 & 0.14 & 0.13 & 0.07 & 0.09 \\
\hline Mg & 0.42 & 0.43 & 0.47 & 0.40 & 0.34 & 0.49 & 0.36 & 0.26 & 0.50 & 0.30 & 0.48 & 0.52 & 0.46 & 0.47 & 0.49 & 0.34 & 0.53 & 0.59 & 0.50 & 0.53 \\
\hline $\mathrm{Mn}$ & 0.01 & 0.01 & 0.01 & 0.02 & 0.01 & 0.01 & 0.02 & 0.01 & 0.01 & 0.02 & 0.02 & 0.02 & 0.01 & 0.02 & 0.01 & 0.02 & 0.02 & 0.01 & 0.02 & 0.02 \\
\hline $\mathrm{Fe}$ & 2.07 & 2.08 & 2.14 & 2.06 & 1.99 & 2.14 & 2.51 & 2.07 & 2.01 & 2.05 & 1.93 & 2.06 & 2.18 & 2.12 & 2.19 & 2.23 & 2.03 & 2.06 & 1.99 & 2.13 \\
\hline $\mathrm{Zn}$ & 0.00 & 0.01 & 0.00 & 0.00 & 0.00 & 0.00 & 0.00 & 0.00 & 0.00 & 0.00 & 0.00 & 0.00 & 0.00 & 0.00 & 0.00 & 0.00 & 0.01 & 0.00 & 0.00 & 0.00 \\
\hline $\mathrm{Ca}$ & 0.01 & 0.02 & 0.02 & 0.02 & 0.00 & 0.01 & 0.01 & 0.00 & 0.02 & 0.00 & 0.02 & 0.01 & 0.01 & 0.01 & 0.01 & 0.01 & 0.11 & 0.12 & 0.01 & 0.02 \\
\hline $\mathrm{Na}$ & 0.70 & 0.70 & 0.72 & 0.68 & 0.68 & 0.89 & 0.96 & 0.68 & 0.80 & 0.68 & 0.73 & 0.82 & 0.92 & 0.88 & 0.90 & 0.71 & 0.70 & 0.69 & 0.81 & 0.88 \\
\hline K & 0.01 & 0.01 & 0.01 & 0.01 & 0.00 & 0.01 & 0.01 & 0.01 & 0.01 & 0.01 & 0.00 & 0.01 & 0.01 & 0.01 & 0.01 & 0.01 & 0.01 & 0.01 & 0.01 & 0.01 \\
\hline \multirow{2}{*}{\multicolumn{21}{|c|}{$\begin{array}{l}\mathrm{B} \\
\mathrm{Li}\end{array}$}} \\
\hline & & & & & & & & & & & & & & & & & & & & \\
\hline vacancies & 0.28 & 0.28 & 0.26 & 0.29 & 0.31 & 0.09 & 0.02 & 0.31 & 0.17 & 0.31 & 0.24 & 0.15 & 0.06 & 0.11 & 0.08 & 0.28 & 0.17 & 0.18 & 0.17 & 0.10 \\
\hline $11 \mathrm{~B} /{ }^{10} \mathrm{~B}$ & 4.024 & 4.025 & 4.017 & 4.009 & 4.016 & 4.002 & 4.008 & 4.006 & 4.028 & 4.002 & 4.038 & 4.019 & 4.033 & 4.028 & 4.030 & 4.018 & 4.005 & 3.997 & 4.010 & 4.009 \\
\hline $1 \sigma(\%)$ & 0.54 & 0.50 & 0.67 & 0.64 & 0.43 & 0.41 & 0.44 & 0.38 & 0.34 & 0.46 & 0.41 & 0.39 & 0.40 & 0.42 & 0.53 & 0.65 & 0.57 & 0.49 & 0.48 & 0.46 \\
\hline$\delta^{11} B$ & -4.8 & -4.6 & -6.7 & -8.5 & -6.7 & -10.3 & -8.7 & -9.3 & -3.9 & -10.3 & -1.3 & -6.2 & -2.6 & -3.9 & -3.4 & -6.4 & -9.5 & -11.6 & -8.2 & -8.5 \\
\hline
\end{tabular}

Analyses by electron microprobe (total $\mathrm{Fe}$ as $\mathrm{FeO}$ ) and by SIMS $\left(\mathrm{H}_{2} \mathrm{O}, \mathrm{Li}_{2} \mathrm{O}, \mathrm{B}_{2} \mathrm{O}_{3}\right.$ and $\mathrm{B}$-isotopes)

a Tourmaline groups: 1- main-stage orbicular tourmaline, 2- veinlets and overgrowths in or on group 1 grains, 3- interstitial grains in granite matrix

${ }^{b}$ calculations based on 15 cations in $T, Z$ and $Y$ sites (Henry and Dutrow, 1996), or based on 31 total anions for samples with $B, H$ and Li data 
Appendix A. Chemical analyses and B isotope ratios of tourmalines from the Erongo granite.

\begin{tabular}{|c|c|c|c|c|c|c|c|c|c|c|c|c|c|c|c|c|c|c|c|c|c|}
\hline \multirow{2}{*}{$\begin{array}{l}\text { Sample } \\
\text { Long. }\left({ }^{\circ} \mathrm{E}\right) \\
\text { Lat. }\left({ }^{\circ} \mathrm{S}\right) \\
\text { Group }^{\mathrm{a}}\end{array}$} & \multicolumn{21}{|c|}{$\begin{array}{l}15^{\circ} 38.1^{\prime} \\
21^{\circ} 50.0^{\prime}\end{array}$} \\
\hline & 1 & 1 & 1 & 1 & 1 & 1 & 1 & 1 & 1 & 1 & 1 & 1 & 2 & 2 & 2 & 2 & 2 & 2 & 2 & 2 & 2 \\
\hline $\mathrm{SiO}_{2}$ (wt.\%) & 36.8 & 35.5 & 35.8 & 35.7 & 36.9 & 35.8 & 34.4 & 34.5 & 34.6 & 34.7 & 34.8 & 34.8 & 37.2 & 35.8 & 37.2 & 36.2 & 34.8 & 35.7 & 35.6 & 35.6 & 37.9 \\
\hline $\mathrm{TiO}_{2}$ & 0.33 & 1.91 & 1.28 & 1.76 & 0.71 & 0.77 & 1.14 & 1.06 & 1.07 & 0.91 & 1.00 & 0.84 & 0.31 & 0.75 & 0.06 & 0.52 & 0.96 & 0.42 & 1.41 & 1.73 & 0.04 \\
\hline $\mathrm{Al}_{2} \mathrm{O}_{3}$ & 33.4 & 27.5 & 29.1 & 28.2 & 29.5 & 30.8 & 30.5 & 30.6 & 30.9 & 31.2 & 31.1 & 31.5 & 31.9 & 30.5 & 32.0 & 30.6 & 31.3 & 32.0 & 28.4 & 27.8 & 32.8 \\
\hline MgO & 1.29 & 2.83 & 2.75 & 2.62 & 1.63 & 1.97 & 2.49 & 2.45 & 2.25 & 2.28 & 2.06 & 1.90 & 1.08 & 2.27 & 1.66 & 2.89 & 1.99 & 1.82 & 2.48 & 2.71 & 1.32 \\
\hline MnO & 0.04 & 0.17 & 0.12 & 0.15 & 0.08 & 0.11 & 0.10 & 0.09 & 0.02 & 0.08 & 0.07 & 0.10 & 0.11 & 0.14 & 0.04 & 0.07 & 0.07 & 0.07 & 0.12 & 0.19 & 0.04 \\
\hline $\mathrm{FeO}$ & 14.1 & 16.4 & 15.5 & 16.2 & 15.5 & 15.0 & 14.4 & 14.7 & 14.7 & 14.7 & 14.9 & 14.4 & 13.7 & 14.8 & 13.9 & 13.9 & 14.6 & 14.5 & 16.4 & 16.9 & 13.1 \\
\hline $\mathrm{ZnO}$ & 0.10 & 0.07 & 0.10 & 0.04 & 0.15 & & & & & & & & 0.07 & 0.00 & 0.10 & & & & 0.09 & 0.15 & 0.13 \\
\hline $\mathrm{CaO}$ & 0.01 & 0.12 & 0.08 & 0.10 & 0.02 & 0.07 & 0.90 & 0.83 & 0.76 & 0.80 & 0.70 & 0.51 & 0.03 & 0.08 & 0.01 & 0.06 & 0.63 & 0.10 & 0.11 & 0.10 & 0.01 \\
\hline $\mathrm{Na}_{2} \mathrm{O}$ & 1.70 & 2.67 & 2.56 & 2.53 & 2.42 & 2.33 & 2.20 & 2.19 & 2.28 & 2.23 & 2.19 & 2.14 & 1.68 & 2.37 & 1.02 & 2.59 & 2.20 & 2.20 & 2.52 & 2.52 & 0.87 \\
\hline $\mathrm{K}_{2} \mathrm{O}$ & 0.04 & 0.07 & 0.05 & 0.07 & 0.03 & 0.06 & 0.07 & 0.08 & 0.07 & 0.08 & 0.08 & 0.06 & 0.03 & 0.04 & 0.01 & 0.03 & 0.08 & 0.04 & 0.05 & 0.06 & 0.01 \\
\hline F & 0.40 & 0.91 & 0.96 & 0.95 & 0.53 & 0.81 & 1.44 & 1.34 & 1.43 & 1.43 & 1.20 & 1.19 & 0.44 & 0.97 & 0.00 & 1.08 & 1.26 & 0.64 & 0.97 & 0.87 & 0.00 \\
\hline$F=0$ & -0.17 & -0.38 & -0.40 & -0.40 & -0.22 & -0.34 & -0.61 & -0.56 & -0.60 & -0.60 & -0.50 & -0.50 & -0.19 & -0.41 & 0.00 & -0.46 & -0.53 & -0.27 & -0.41 & -0.37 & 0.00 \\
\hline $\mathrm{H}_{2} \mathrm{O}$ & 2.46 & 2.46 & 2.34 & & & & & & & & & & 2.31 & 2.40 & 2.22 & & & & & & \\
\hline $\mathrm{Li}_{2} \mathrm{O}$ & 0.02 & 0.01 & 0.01 & & & & & & & & & & 0.01 & 0.01 & 0.01 & & & & & & \\
\hline $\mathrm{B}_{2} \mathrm{O}_{3}$ & 10.51 & 10.66 & 10.70 & & & & & & & & & & 10.18 & 10.28 & 10.24 & & & & & & \\
\hline Sum & 101.0 & 100.9 & 100.9 & 87.9 & 87.3 & 87.4 & 87.0 & 87.3 & 87.4 & 87.7 & 87.6 & 86.9 & 98.9 & 100.0 & 98.5 & 87.5 & 87.3 & 87.2 & 87.7 & 88.3 & 86.2 \\
\hline \multicolumn{22}{|l|}{ Atoms p.f.u. ${ }^{b}$} \\
\hline Si & 6.15 & 6.04 & 6.06 & 6.09 & 6.31 & 6.08 & 5.93 & 5.92 & 5.92 & 5.92 & 5.94 & 5.96 & 6.08 & 6.08 & 6.40 & 6.13 & 5.95 & 6.04 & 6.08 & 6.06 & 6.33 \\
\hline $\mathrm{Al}(\mathrm{T})$ & 0.00 & 0.00 & 0.00 & 0.00 & 0.00 & 0.00 & 0.07 & 0.08 & 0.08 & 0.08 & 0.06 & 0.04 & 0.00 & 0.00 & 0.00 & 0.00 & 0.05 & 0.00 & 0.00 & 0.00 & 0.00 \\
\hline $\mathrm{Al}(\mathrm{Z})$ & 6.00 & 5.52 & 5.80 & 5.68 & 5.94 & 6.00 & 6.00 & 6.00 & 6.00 & 6.00 & 6.00 & 6.00 & 0.06 & 6.00 & 6.00 & 6.00 & 6.00 & 6.00 & 5.73 & 5.58 & 6.00 \\
\hline $\mathrm{Al}(\mathrm{Y})$ & 0.58 & 0.00 & 0.00 & 0.00 & 0.00 & 0.17 & 0.12 & 0.11 & 0.18 & 0.19 & 0.20 & 0.33 & 0.00 & 0.10 & 0.49 & 0.10 & 0.27 & 0.39 & 0.00 & 0.00 & 0.47 \\
\hline $\mathrm{Ti}$ & 0.04 & 0.24 & 0.16 & 0.23 & 0.09 & 0.10 & 0.15 & 0.14 & 0.14 & 0.12 & 0.13 & 0.11 & 4.78 & 0.10 & 0.01 & 0.07 & 0.12 & 0.05 & 0.18 & 0.22 & 0.00 \\
\hline Mg & 0.32 & 0.72 & 0.69 & 0.67 & 0.42 & 0.50 & 0.64 & 0.63 & 0.58 & 0.58 & 0.52 & 0.48 & 8.11 & 0.57 & 0.43 & 0.73 & 0.51 & 0.46 & 0.63 & 0.69 & 0.33 \\
\hline$M n$ & 0.01 & 0.02 & 0.02 & 0.02 & 0.01 & 0.02 & 0.01 & 0.01 & 0.00 & 0.01 & 0.01 & 0.01 & 0.16 & 0.02 & 0.01 & 0.01 & 0.01 & 0.01 & 0.02 & 0.03 & 0.01 \\
\hline $\mathrm{Fe}$ & 1.98 & 2.34 & 2.19 & 2.32 & 2.21 & 2.13 & 2.08 & 2.12 & 2.10 & 2.10 & 2.13 & 2.06 & 0.02 & 2.10 & 2.00 & 1.97 & 2.09 & 2.05 & 2.34 & 2.41 & 1.84 \\
\hline $\mathrm{Zn}$ & 0.01 & 0.01 & 0.01 & 0.00 & 0.02 & 0.00 & 0.00 & 0.00 & 0.00 & 0.00 & 0.00 & 0.00 & 1.73 & 0.00 & 0.01 & 0.00 & 0.00 & 0.00 & 0.01 & 0.02 & 0.02 \\
\hline $\mathrm{Ca}$ & 0.00 & 0.02 & 0.01 & 0.02 & 0.00 & 0.01 & 0.17 & 0.15 & 0.14 & 0.15 & 0.13 & 0.09 & 0.01 & 0.01 & 0.00 & 0.01 & 0.12 & 0.02 & 0.02 & 0.02 & 0.00 \\
\hline $\mathrm{Na}$ & 0.55 & 0.88 & 0.84 & 0.84 & 0.80 & 0.77 & 0.74 & 0.73 & 0.76 & 0.74 & 0.73 & 0.71 & 0.01 & 0.78 & 0.34 & 0.85 & 0.73 & 0.72 & 0.83 & 0.83 & 0.28 \\
\hline K & 0.01 & 0.02 & 0.01 & 0.01 & 0.01 & 0.01 & 0.01 & 0.02 & 0.01 & 0.02 & 0.02 & 0.01 & 0.36 & 0.01 & 0.00 & 0.01 & 0.02 & 0.01 & 0.01 & 0.01 & 0.00 \\
\hline B & 3.04 & 3.13 & 3.12 & & & & & & & & & & 3.00 & 3.01 & 3.04 & & & & & & \\
\hline $\mathrm{Li}$ & 0.01 & 0.01 & 0.01 & & & & & & & & & & 0.01 & 0.01 & 0.00 & & & & & & \\
\hline $\mathrm{H}$ & 2.75 & 2.80 & 2.64 & & & & & & & & & & 2.63 & 2.72 & 2.55 & & & & & & \\
\hline vacancies & 0.44 & 0.08 & 0.14 & 0.13 & 0.19 & 0.21 & 0.08 & 0.10 & 0.09 & 0.10 & 0.13 & 0.18 & 0.61 & 0.20 & 0.66 & 0.13 & 0.14 & 0.25 & 0.14 & 0.14 & 0.72 \\
\hline $11 \mathrm{~B} /{ }^{10} \mathrm{~B}$ & 4.018 & 4.011 & 4.012 & 4.006 & 4.014 & 4.012 & 4.005 & 4.003 & 4.006 & 4.003 & 4.009 & 4.013 & 4.035 & 4.024 & 4.034 & 4.018 & 4.009 & 4.028 & 4.012 & 4.033 & 4.038 \\
\hline $1 \sigma(\%)$ & 0.71 & 0.67 & 0.60 & 0.63 & 0.73 & 0.77 & 0.48 & 0.41 & 0.58 & 0.56 & 0.52 & 0.56 & 0.68 & 0.53 & 0.56 & 0.43 & 0.44 & 0.64 & 0.65 & 0.52 & 0.69 \\
\hline$\delta^{11} \mathrm{~B}$ & -6.5 & -8.0 & -7.7 & -9.3 & -7.2 & -7.7 & -9.5 & -10.0 & -9.3 & -10.0 & -8.5 & -7.5 & -2.1 & -4.9 & -2.3 & -6.5 & -8.5 & -3.9 & -7.7 & -2.6 & -1.3 \\
\hline
\end{tabular}

Analyses by electron microprobe (total Fe as $\mathrm{FeO}$ ) and by SIMS ( $\mathrm{t}_{2} \mathrm{O}, \mathrm{Li} \mathrm{O}_{2}, \mathrm{~B}_{2} \mathrm{O}_{3}$ and $\mathrm{B}$-isotopes)

${ }^{a}$ Tourmaline groups: 1- main-stage orbicular tourmaline, 2- veinlets and overgrowths in or on group 1 grains, 3- interstitial grains in granite matrix

${ }^{\mathrm{b}}$ calculations based on 15 cations in $\mathrm{T}, \mathrm{Z}$ and $\mathrm{Y}$ sites (Henry and Dutrow, 1996), or based on 31 total anions for samples with B, H and Li data 
Appendix B. Chemical analyses and B isotope ratios of tourmalines from the basement samples.

\begin{tabular}{|c|c|c|c|c|c|c|c|c|c|c|c|c|c|}
\hline \multirow{2}{*}{$\begin{array}{l}\text { Sample } \\
\left.\text { Long. ( }{ }^{\circ} \mathrm{E}\right) \\
\left.\text { Lat. ( }{ }^{\circ} \mathrm{S}\right) \\
\text { Group }^{\mathrm{a}}\end{array}$} & \multicolumn{2}{|c|}{$\begin{array}{l}2682-1 \\
15^{\circ} 33.9^{\prime} \\
21^{\circ} 15.8^{\prime}\end{array}$} & \multicolumn{2}{|c|}{$\begin{array}{l}391 a \\
16^{\circ} 13.7^{\prime} \\
22^{\circ} 42.9^{\prime}\end{array}$} & \multirow[b]{2}{*}{$\mathrm{M}$} & \multirow[b]{2}{*}{$\mathrm{M}$} & \multicolumn{2}{|c|}{$\begin{array}{l}2588-6 \\
15^{\circ} 42.2^{\prime} \\
21^{\circ} 13.6^{\prime}\end{array}$} & \multicolumn{2}{|c|}{$\begin{array}{l}248-8 \\
15^{\circ} 42.9^{\prime} \\
21^{\circ} 13.3^{\prime}\end{array}$} & \multicolumn{2}{|c|}{$\begin{array}{l}2583-6 \\
15^{\circ} 41.3^{\prime} \\
21^{\circ} 15.0^{\prime}\end{array}$} & \multirow[b]{2}{*}{$\mathrm{T}$} \\
\hline & $\mathrm{P}$ & $\mathrm{P}$ & $\mathrm{M}$ & $\mathrm{M}$ & & & $\mathrm{T}$ & $\mathrm{T}$ & $\mathrm{M}$ & $\mathrm{M}$ & $\mathrm{T}$ & $\mathrm{T}$ & \\
\hline $\mathrm{SiO}_{2}(w t . \%)$ & 35.9 & 35.6 & 37.8 & 37.5 & 37.8 & 36.9 & 37.1 & 37.3 & 35.4 & 36.1 & 37.2 & 37.3 & 37.5 \\
\hline $\mathrm{TiO}_{2}$ & 0.51 & 0.62 & 0.25 & 0.49 & 0.28 & 1.05 & 0.65 & 0.72 & 1.18 & 0.91 & 0.58 & 0.63 & 0.37 \\
\hline $\mathrm{Al}_{2} \mathrm{O}_{3}$ & 33.4 & 33.1 & 34.4 & 33.8 & 34.2 & 30.1 & 33.2 & 33.1 & 31.9 & 31.0 & 32.6 & 32.8 & 33.4 \\
\hline $\mathrm{MgO}$ & 1.50 & 1.22 & 6.58 & 6.73 & 6.57 & 5.94 & 6.45 & 6.41 & 4.44 & 4.95 & 7.67 & 7.42 & 7.37 \\
\hline MnO & 0.17 & 0.20 & 0.01 & 0.04 & 0.01 & 0.04 & 0.08 & 0.02 & 0.30 & 0.36 & 0.00 & 0.05 & 0.02 \\
\hline $\begin{array}{l}\mathrm{FeO} \\
\mathrm{ZnO}\end{array}$ & 13.7 & 14.3 & 6.0 & 5.8 & 6.0 & 10.1 & 6.9 & 7.0 & 10.6 & 10.4 & 5.3 & 5.3 & 5.1 \\
\hline $\mathrm{CaO}$ & 0.04 & 0.05 & 0.54 & 0.73 & 0.55 & 0.57 & 0.63 & 0.64 & 0.88 & 0.91 & 1.21 & 1.13 & 0.96 \\
\hline $\mathrm{Na}_{2} \mathrm{O}$ & 1.93 & 2.00 & 1.56 & 1.69 & 1.58 & 2.23 & 2.16 & 2.12 & 2.12 & 2.09 & 1.84 & 1.77 & 1.88 \\
\hline $\mathrm{K}_{2} \mathrm{O}$ & 0.05 & 0.04 & 0.03 & 0.02 & 0.00 & 0.01 & 0.07 & 0.04 & 0.05 & 0.05 & 0.01 & 0.01 & 0.03 \\
\hline F & 0.14 & 0.11 & & & & & & & 0.48 & 0.51 & 0.08 & 0.11 & 0.08 \\
\hline$F=0$ & -0.06 & -0.05 & & & & & & & -0.20 & -0.22 & -0.03 & -0.05 & -0.04 \\
\hline $\mathrm{H}_{2} \mathrm{O}$ & 2.33 & 2.40 & & & & & & & & & 1.86 & 1.69 & \\
\hline $\mathrm{Li}_{2} \mathrm{O}$ & 0.01 & 0.01 & & & & & & & & & 0.00 & 0.00 & \\
\hline $\mathrm{B}_{2} \mathrm{O}_{3}$ & 10.35 & 10.33 & & & & & & & & & 9.63 & 9.56 & \\
\hline Sum & 99.9 & 100.0 & 87.3 & 86.8 & 87.0 & 86.9 & 87.2 & 87.3 & 87.1 & 87.0 & 97.9 & 97.8 & 86.7 \\
\hline \multicolumn{14}{|l|}{ Atoms p.f.u. ${ }^{b}$} \\
\hline $\mathrm{Si}$ & 6.10 & 6.08 & 6.07 & 6.08 & 6.09 & 6.11 & 6.03 & 6.07 & 5.92 & 6.04 & 6.29 & 6.33 & 6.08 \\
\hline $\operatorname{Al}(\mathrm{T})$ & 0.00 & 0.00 & 0.00 & 0.00 & 0.00 & 0.00 & 0.00 & 0.00 & 0.08 & 0.00 & 0.00 & 0.00 & 0.00 \\
\hline $\mathrm{Al}(\mathrm{Z})$ & 6.00 & 6.00 & 6.00 & 6.00 & 6.00 & 5.89 & 6.00 & 6.00 & 6.00 & 6.00 & 6.00 & 6.00 & 6.00 \\
\hline $\mathrm{Al}(\mathrm{Y})$ & 0.69 & 0.66 & 0.51 & 0.45 & 0.49 & 0.00 & 0.37 & 0.34 & 0.21 & 0.11 & 0.50 & 0.56 & 0.40 \\
\hline $\mathrm{Ti}$ & 0.06 & 0.08 & 0.03 & 0.06 & 0.03 & 0.13 & 0.08 & 0.09 & 0.15 & 0.11 & 0.07 & 0.08 & 0.04 \\
\hline Mg & 0.38 & 0.31 & 1.57 & 1.62 & 1.58 & 1.47 & 1.56 & 1.55 & 1.11 & 1.23 & 1.93 & 1.87 & 1.78 \\
\hline Mn & 0.02 & 0.03 & 0.00 & 0.01 & 0.00 & 0.01 & 0.01 & 0.00 & 0.04 & 0.05 & 0.00 & 0.01 & 0.00 \\
\hline $\mathrm{Fe}$ & 1.95 & 2.04 & 0.81 & 0.78 & 0.81 & 1.40 & 0.94 & 0.95 & 1.49 & 1.45 & 0.75 & 0.75 & 0.69 \\
\hline $\mathrm{Zn}$ & 0.00 & 0.00 & 0.00 & 0.00 & 0.00 & 0.00 & 0.00 & 0.00 & 0.00 & 0.00 & 0.00 & 0.00 & 0.00 \\
\hline $\mathrm{Ca}$ & 0.01 & 0.01 & 0.09 & 0.13 & 0.10 & 0.10 & 0.11 & 0.11 & 0.16 & 0.16 & 0.22 & 0.20 & 0.17 \\
\hline $\mathrm{Na}$ & 0.64 & 0.66 & 0.49 & 0.53 & 0.49 & 0.72 & 0.68 & 0.67 & 0.69 & 0.68 & 0.60 & 0.58 & 0.59 \\
\hline K & 0.01 & 0.01 & 0.01 & 0.00 & 0.00 & 0.00 & 0.01 & 0.01 & 0.01 & 0.01 & 0.00 & 0.00 & 0.01 \\
\hline B & 3.04 & 3.04 & & & & & & & & & 2.81 & 2.80 & \\
\hline $\mathrm{Li}$ & 0.01 & 0.01 & & & & & & & & & 0.00 & 0.00 & \\
\hline H & 2.64 & 2.73 & & & & & & & & & 2.10 & 1.91 & \\
\hline vacancies & 0.35 & 0.32 & 0.42 & 0.34 & 0.41 & 0.18 & 0.20 & 0.21 & 0.15 & 0.15 & 0.17 & 0.21 & 0.24 \\
\hline $\begin{array}{l}{ }^{11} B / /^{10} B \\
1 \sigma(\%)\end{array}$ & $\begin{array}{l}4.011 \\
0.61\end{array}$ & $\begin{array}{l}4.006 \\
0.95\end{array}$ & $\begin{array}{l}4.012 \\
0.74\end{array}$ & $\begin{array}{l}4.014 \\
0.68\end{array}$ & $\begin{array}{l}4.012 \\
0.60\end{array}$ & $\begin{array}{l}4.016 \\
0.66\end{array}$ & $\begin{array}{l}4.011 \\
0.52\end{array}$ & $\begin{array}{l}4.011 \\
0.61\end{array}$ & $\begin{array}{l}3.992 \\
0.56\end{array}$ & $\begin{array}{l}3.989 \\
0.57\end{array}$ & $\begin{array}{l}4.010 \\
0.82\end{array}$ & $\begin{array}{l}4.003 \\
0.87\end{array}$ & $\begin{array}{l}3.996 \\
0.83\end{array}$ \\
\hline$\delta^{11} \mathrm{~B}$ & -8.0 & -9.3 & -7.7 & -7.2 & -7.7 & -6.7 & -8.0 & -8.0 & -12.6 & -13.4 & -8.4 & -10.0 & -11.8 \\
\hline
\end{tabular}

Analyses by electron microprobe (total $\mathrm{Fe}$ as $\mathrm{FeO})$ and by $\mathrm{SIMS}\left(\mathrm{H}_{2} \mathrm{O}, \mathrm{Li}_{2} \mathrm{O}, \mathrm{B}_{2} \mathrm{O}_{3}\right.$ and $\mathrm{B}$-isotopes)

${ }^{a}$ Tourmaline groups: $\mathrm{P}$ - tourmaline from pegmatite dikes, $\mathrm{M}$ - tourmaline from metapelite, $\mathrm{T}$ - tourmaline from tourmalinite

${ }^{\mathrm{b}}$ calculations based on 15 cations in $\mathrm{T}, \mathrm{Z}$ and $\mathrm{Y}$ sites (Henry and Dutrow, 1996), or based on 31 total anions for samples with B, H and Li data 